\title{
Synthesis and preliminary biological evaluation of radiolabeled 5-BDBD analogs as new candidate PET radioligands for P2X4 receptor
}

Min Wang, Mingzhang Gao, Jill A. Meyer, Jonathan S. Peters, Hamideh Zarrinmayeh, Paul R. Territo, Gary D. Hutchins, Qi-Huang Zheng*

Department of Radiology and Imaging Sciences, Indiana University School of Medicine, 1345 West $16^{\text {th }}$ Street, L3-208, Indianapolis, IN 46202, USA

\section{*Corresponding author:}

Qi-Huang Zheng, Ph.D.

Department of Radiology

Indiana University School of Medicine

1345 West $16^{\text {th }}$ Street, L3-208

Indianapolis, IN 46202-2111

USA

Tel: 317-278-4671

Fax: 317-278-9711

E-mail: qzheng@iupui.edu

This is the author's manuscript of the article published in final edited form as:

Wang, M., Gao, M., Meyer, J. A., Peters, J. S., Zarrinmayeh, H., Territo, P. R., ... Zheng, Q.-H. (2017). Synthesis and preliminary biological evaluation of radiolabeled 5-BDBD analogs as new candidate PET radioligands for P2X4 receptor. Bioorganic \& Medicinal Chemistry. https://doi.org/10.1016/j.bmc.2017.05.031 


\section{Abstract:}

P2X4 receptor has become an interesting molecular target for treatment and PET imaging of neuroinflammation and associated brain diseases such as Alzheimer's disease. This study reports the first design, synthesis, radiolabeling and biological evaluation of new candidate PET P2X4 receptor radioligands using 5-BDBD, a specific $\mathrm{P} 2 \mathrm{X} 4$ receptor antagonist, as a scaffold. 5-(3Hydroxyphenyl)-1-[ $\left[{ }^{11} \mathrm{C}\right]$ methyl-1,3-dihydro-2H-benzofuro[3,2-e $][1,4]$ diazepin-2-one $(N-$ $\left[{ }^{11} \mathrm{C}\right] \mathrm{Me}-5-\mathrm{BDBD}$ analog, $\left.\left[{ }^{11} \mathrm{C}\right] 9\right)$ and 5-(3-Bromophenyl)-1-[ $\left.{ }^{11} \mathrm{C}\right]$ methyl-1,3-dihydro- $\mathrm{H}$ benzofuro[3,2-e][1,4]diazepin-2-one $\left(N-\left[{ }^{11} \mathrm{C}\right] \mathrm{Me}-5-\mathrm{BDBD},\left[{ }^{11} \mathrm{C}\right] \mathbf{8 c}\right)$ were prepared from their corresponding desmethylated precursors with $\left[{ }^{11} \mathrm{C} \mathrm{CH}_{3} \mathrm{OTf}\right.$ through $N-\left[{ }^{11} \mathrm{C}\right]$ methylation and isolated by HPLC combined with SPE in 30-50\% decay corrected radiochemical yields with 370-1110 GBq/ $\mu \mathrm{mol}$ specific activity at EOB. 5-(3- $\left[{ }^{18} \mathrm{~F}\right]$ Fluorophenyl)-1,3-dihydro- $2 \mathrm{H}$ benzofuro[3,2-e][1,4]diazepin-2-one $\left(\left[{ }^{18} \mathrm{~F}\right] \mathrm{F}-5-\mathrm{BDBD}, \quad\left[{ }^{18} \mathrm{~F}\right] \mathbf{5 a}\right) \quad$ and $\quad$ 5-(3-(2$\left[{ }^{18}\right.$ F $]$ fluoroethoxy)phenyl)-1,3-dihydro-2 $H$-benzofuro[3,2-e $][1,4]$ diazepin-2-one $\quad\left(\left[{ }^{18}\right.\right.$ F $]$ FE-5BDBD, $\left.\left[{ }^{18} \mathrm{~F}\right] \mathbf{1 1}\right)$ were prepared from their corresponding nitro- and tosylated precursors by nucleophilic substitution with $\mathrm{K}\left[{ }^{18} \mathrm{~F}\right] \mathrm{F} / \mathrm{Kryptofix} 2.2 .2$ and isolated by HPLC-SPE in 5-25\% decay corrected radiochemical yields with $111-740 \mathrm{GBq} / \mu$ mol specific activity at EOB. The preliminary biological evaluation of radiolabeled 5-BDBD analogs indicated these new radioligands have similar biological activity with their parent compound 5-BDBD.

Keywords: Radiolabeled 5-BDBD analogs; P2X4 receptor; Radiosynthesis; Radioligand depletion experiment; Competitive binding assay; Positron emission tomography (PET). 


\section{Introduction}

The purinergic $\mathrm{P} 2 \mathrm{X}$ receptors are a family of cation-permeable ligand gated ion channels that open in response to the binding of extracellular adenosine 5'-triphosphate (ATP). ${ }^{1}$ This ionotropic receptor family contains seven subunits $\mathrm{P} 2 \mathrm{X} 1-7 . \mathrm{P} 2 \mathrm{X}$ receptors are involved in various physiological processes and associated with a variety of diseases including cancer, cardiovascular and neurological diseases. ${ }^{2} \mathrm{P} 2 \mathrm{X} 7$ and $\mathrm{P} 2 \mathrm{X} 4$ receptors are two predominant subtypes expressed on immune and neural cells. The over expression of P2X7 and P2X4 receptors is linked to neuroinflammation, which is an essential step in the progression of brain diseases. ${ }^{3}$ Both $\mathrm{P} 2 \mathrm{X} 7$ and $\mathrm{P} 2 \mathrm{X} 4$ receptors have become a novel molecular target for treatment and PET (positron emission tomography) imaging of neuroinflammation and associated brain diseases such as Alzheimer's disease. ${ }^{4}$ In our previous work, we have developed $\left[{ }^{11} \mathrm{C}\right] \mathrm{GSK} 1482160^{5,6}$ as a new PET probe for imaging of P2X7 receptor as indicated in Figure 1. In this ongoing study, we first target $\mathrm{P} 2 \mathrm{X} 4$ receptor and develop PET $\mathrm{P} 2 \mathrm{X} 4$ receptor radioligands. Despite the therapeutic potential of P2X4 receptor antagonists, only a very limited number of inhibitors are known so far. Subsequently, the structure-activity relationship (SAR) information of $\mathrm{P} 2 \mathrm{X} 4$ receptor antagonists is limited as well. However, potent and selective $\mathrm{P} 2 \mathrm{X} 4$ receptor antagonists are required as research tools for investigating the physiological functions of P2X4 receptor. 5-BDBD (5-(3-bromophenyl)-1,3-dihydro-2H-benzofuro[3,2-e][1,4]diazepin-2one) is a specific $\mathrm{P} 2 \mathrm{X} 4$ receptor antagonist with an $\mathrm{IC}_{50}$ of $500 \mathrm{nM}$ in Chinese hamster ovary cells $(\mathrm{CHO}) .^{7}$ Here we report the design, synthesis, radiolabeling and preliminary biological evaluation of a series of radiolabeled 5-BDBD analogs as new candidate $\mathrm{P} 2 \mathrm{X} 4$ receptor radioligands as shown in Figure 2. 
<smiles>CN1C(=O)CCC1C(=O)NCc1cccc(C(F)(F)F)c1Cl</smiles>

GSK1482160, P2X7 ligand<smiles></smiles>

$\left[{ }^{11} \mathrm{C}\right] \mathrm{GSK} 1482160, \mathrm{P} 2 \mathrm{X} 7$ radioligand

Figure 1. P2X7 receptor ligand GSK1482160 and radioligand $\left[{ }^{11} \mathrm{C}\right] \mathrm{GSK} 1482160$.
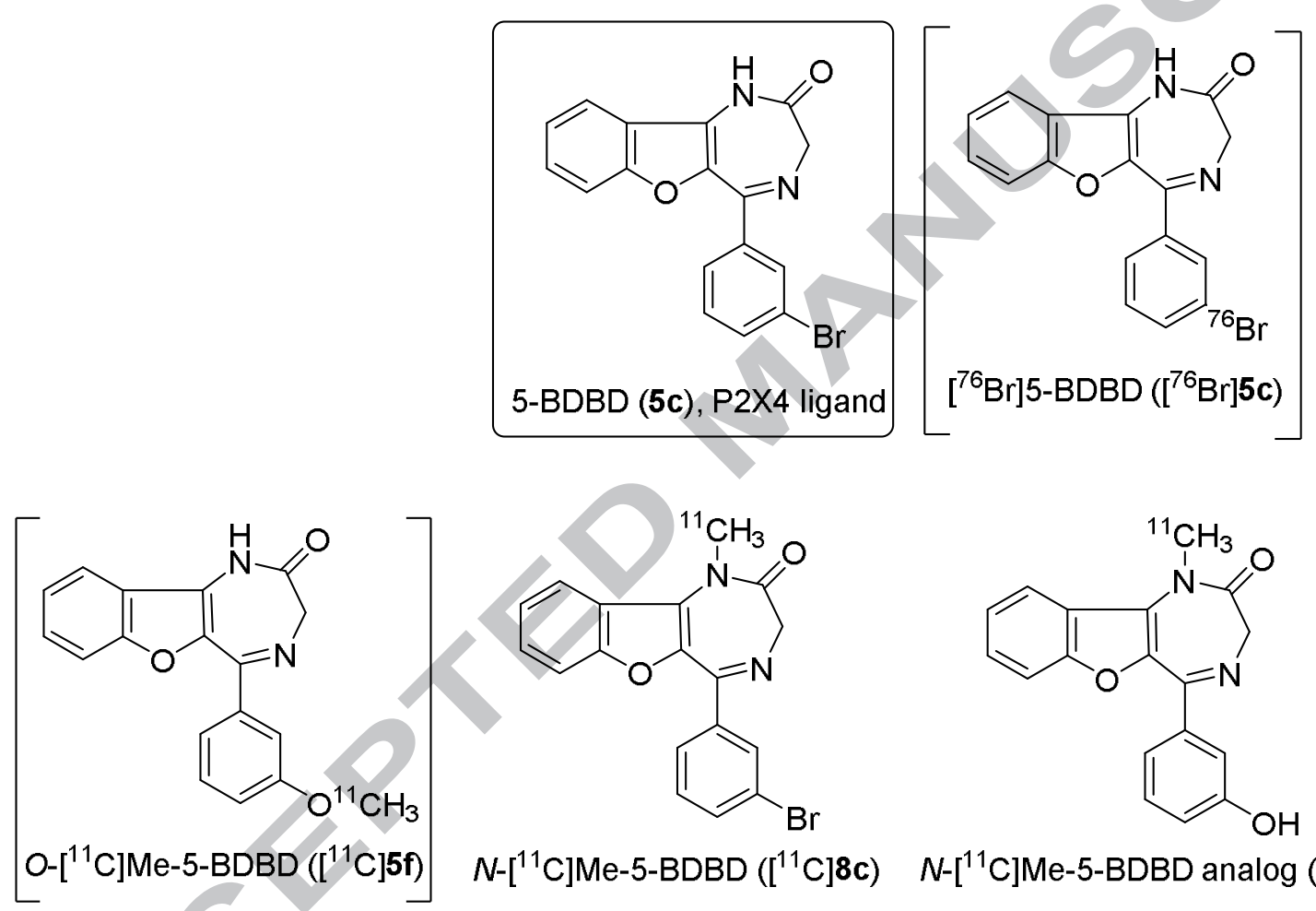<smiles>CN1C(=O)CN=C(c2cccc(O)c2)c2oc3ccccc3c21</smiles>

$N-\left[{ }^{11} \mathrm{C}\right]$ Me-5-BDBD $\left(\left[\left[^{11} \mathrm{C}\right] 8 \mathrm{C}\right) \quad N-\left[{ }^{11} \mathrm{C}\right] \mathrm{Me}-5-\mathrm{BDBD}\right.$ analog $\left(\left[{ }^{11} \mathrm{C}\right] 9\right)$<smiles>O=C1CN=C(c2cccc(F)c2)c2oc3ccccc3c2N1</smiles>

$\left[{ }^{18} \mathrm{~F}\right] \mathrm{F}-5-\mathrm{BDBD}\left(\left[{ }^{18} \mathrm{~F}\right] \mathbf{5 a}\right)$<smiles>O=C1CN=C(c2cccc(OCC[18F])c2)c2oc3ccccc3c2N1</smiles>

$\left[{ }^{18} \mathrm{~F}\right] \mathrm{FE}-5-\mathrm{BDBD}\left(\left[{ }^{18} \mathrm{~F}\right] 11\right)$

Figure 2. P2X4 receptor antagonist 5-BDBD and radiolabeled 5-BDBD analogs. 


\section{Results and discussion}

\subsection{Chemistry}

5-BDBD can be directly radiolabeled with bromine-76 as $\left[{ }^{76} \mathrm{Br}\right] 5-\mathrm{BDBD}\left(\left[{ }^{76} \mathrm{Br}\right] \mathbf{5 c}\right)$ using either chloro-precursor or tributylstannyl precursor., ${ }^{8,9}$ However, our cyclotron does not produce bromine-76, thus we focus on the synthesis of carbon-11 and fluorine-18 labeled 5-BDBD analogs. The novel P2X4 receptor radioligands proposed for development are based on direct $N$ $\left[{ }^{11} \mathrm{C}\right]$ methylation at amide position of 5-BDBD and replacement of the bromo group of 5-BDBD with an $O$ - $\left[{ }^{11} \mathrm{C}\right]$ methoxy, $\left[{ }^{18} \mathrm{~F}\right]$ fluoro or $\left[{ }^{18} \mathrm{~F}\right]$ fluoroethoxy group. Our initial design is to synthesize $O-\left[{ }^{11} \mathrm{C}\right] \mathrm{Me}-5-\mathrm{BDBD} \quad\left(\left[{ }^{11} \mathrm{C}\right] \mathbf{5 f}\right), \quad N-\left[{ }^{11} \mathrm{C}\right] \mathrm{Me}-5-\mathrm{BDBD} \quad\left(\left[{ }^{11} \mathrm{C}\right] \mathbf{8 c}\right), \quad\left[{ }^{18} \mathrm{~F}\right] \mathrm{F}-5-\mathrm{BDBD}$ $\left(\left[{ }^{18} \mathrm{~F}\right] \mathbf{5 a}\right)$ and $\left[{ }^{18} \mathrm{~F}\right] \mathrm{FE}-5-\mathrm{BDBD}\left(\left[{ }^{18} \mathrm{~F}\right] \mathbf{1 1}\right)$ (Figure 2$)$.

5-(3-Substituted phenyl)-1,3-dihydro-2H-benzofuro[3,2-e][1,4]diazepin-2-one analogs 5a-5f were synthesized as outlined in Scheme 1. Starting from commercially available 2hydroxybenzonitrile, it underwent alkylation with 3-substituted phenacyl bromides 1a-1f in the presence of $\mathrm{Na}_{2} \mathrm{CO}_{3}$ in $N, N$-dimethylformamide (DMF) to obtain intermediate 2-(2-(3substituted phenyl)-2-oxoethoxy)benzonotriles 2a-2f, which were cyclized with sodium methoxide in $\mathrm{MeOH}$ to provide (3-aminobenzofuran-2-yl)-(3-substituted phenyl)methanones 3a-

3f in yields $82-98 \% .{ }^{10}$ As shown in Scheme 1, compound 1d was achieved by $\alpha$-bromination of 3-iodoacetophenone with copper (II) bromide in EtOAc/ $\mathrm{CHCl}_{3}$ in $67 \%$ yield. ${ }^{11,12}$ Acylation of 
amines 3a-3f with bromoacetyl bromide in the presence of $\mathrm{NaHCO}_{3}$ in $\mathrm{CHCl}_{3}$ afforded 2-bromo$N$-(2-(3-substituted benzoyl)benzofuran-3-yl)acetamide 4a-4f in yields $75-89 \%$. Treatment of 4a-4f with ammonia in dioxane for cyclization to give $\mathbf{5 a - 5 f}$ in yields $58-92 \%{ }^{13}$<smiles>CCOC(=O)C(C)(C)C(C)(C)C</smiles><smiles>[R]c1cccc(C(=O)CBr)c1</smiles>

1a: $\mathrm{R}=\mathrm{F}$

1b: $\mathrm{R}=\mathrm{Cl}$

1c: $\mathrm{R}=\mathrm{Br}$

1d: $R=1$

1e: $\mathrm{R}=\mathrm{NO}_{2}$

1f. $\mathrm{R}=\mathrm{OCH}_{3}$

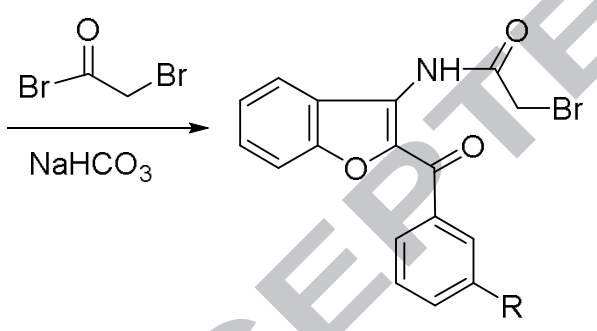

$$
\begin{aligned}
& \text { 4a: } \mathrm{R}=\mathrm{F} \\
& \text { 4b: } \mathrm{R}=\mathrm{Cl} \\
& \text { 4c: } \mathrm{R}=\mathrm{Br} \\
& \text { 4d: } \mathrm{R}=\mathrm{I} \\
& \text { 4e: } \mathrm{R}=\mathrm{NO}_{2} \\
& \text { 4f: } \mathrm{R}=\mathrm{OCH}_{3}
\end{aligned}
$$
2a: $R=F$
2b: $\mathrm{R}=\mathrm{Cl}$
2c: $\mathrm{R}=\mathrm{Br}$
2d: $R=I$
2e: $\mathrm{R}=\mathrm{NO}_{2}$
2f: $\mathrm{R}=\mathrm{OCH}_{3}$<smiles>[R]c1cccc(C(=O)c2oc3ccccc3c2N)c1</smiles>

3a: $R=F$

3b: $\mathrm{R}=\mathrm{Cl}$

3c: $\mathrm{R}=\mathrm{Br}$

3d: $R=1$

3e: $\mathrm{R}=\mathrm{NO}_{2}$ 3f: $\mathrm{R}=\mathrm{OCH}_{3}$

Scheme 1. Synthesis of 5-BDBD analogs 5a-5f. 
<smiles>COc1cccc(C2=NCC(=O)Nc3c2oc2ccccc32)c1</smiles><smiles>[R]c1cccc(C2=NCC(=O)Nc3c2oc2ccccc32)c1</smiles>

5c: $\mathrm{R}=\mathrm{Br}$ 5f. $\mathrm{R}=\mathrm{OCH}_{3}$<smiles>O=C1CN=C(c2cccc(O)c2)c2oc3ccccc3c2N1</smiles>

6<smiles>[R]c1cccc(C2=NCC(=O)N(C)c3c2oc2ccccc32)c1</smiles>

8c: $\mathrm{R}=\mathrm{Br}(\mathrm{N}-\mathrm{Me}-5-\mathrm{BDBD})$ 8f: $\mathrm{R}=\mathrm{OCH}_{3}$<smiles>O=C1CN=C(c2cccc(OCCF)c2)c2oc3ccccc3c2N1</smiles>

11 (FE-5-BDBD)

Scheme 2. Synthesis of 5-BDBD analogs 6, 8c, 8f, 10 and 11.

As depicted in Scheme 2, desmethylation ${ }^{14,15}$ of $\mathbf{5 f}$ with $\mathrm{BBr}_{3}$ in $\mathrm{CH}_{2} \mathrm{Cl}_{2}$ afforded the precursor 5(3-hydroxyphenyl)-1,3-dihydro-2H-benzofuro[3,2-e][1,4]diazepin-2-one $\quad(6)$ in $81 \%$ yield. Methylation of 5c, 5f with $\mathrm{CH}_{3} \mathrm{I}$ in the presence of $\mathrm{NaH}$ in DMF gave $N$ methylbenzodiazepinone 8c, $8 \mathbf{8}$ in $65 \%$ and $90 \%$ yield, respectively. $O$-alkylation of $\mathbf{6}$ with $1,2-$ 
bis(tosyloxy)ethane or 2-fluoroethyl tosylate in the presence of $\mathrm{NaH}$ in $\mathrm{DMF},{ }^{16}$ gave the tosylated 2-(3-(2-oxo-2,3-dihydro-1H-benzofuro[3,2-e][1,4]diazepin-5yl)phenoxy)ethyl 4-methylbenzenesulfonate (10) and reference standard 5-(3-(2fluoroethoxy)phenyl)-1,3-dihydro-2H-benzofuro[3,2-e][1,4]diazepin-2-one (11) in 65\% and $43 \%$ yield, respectively.

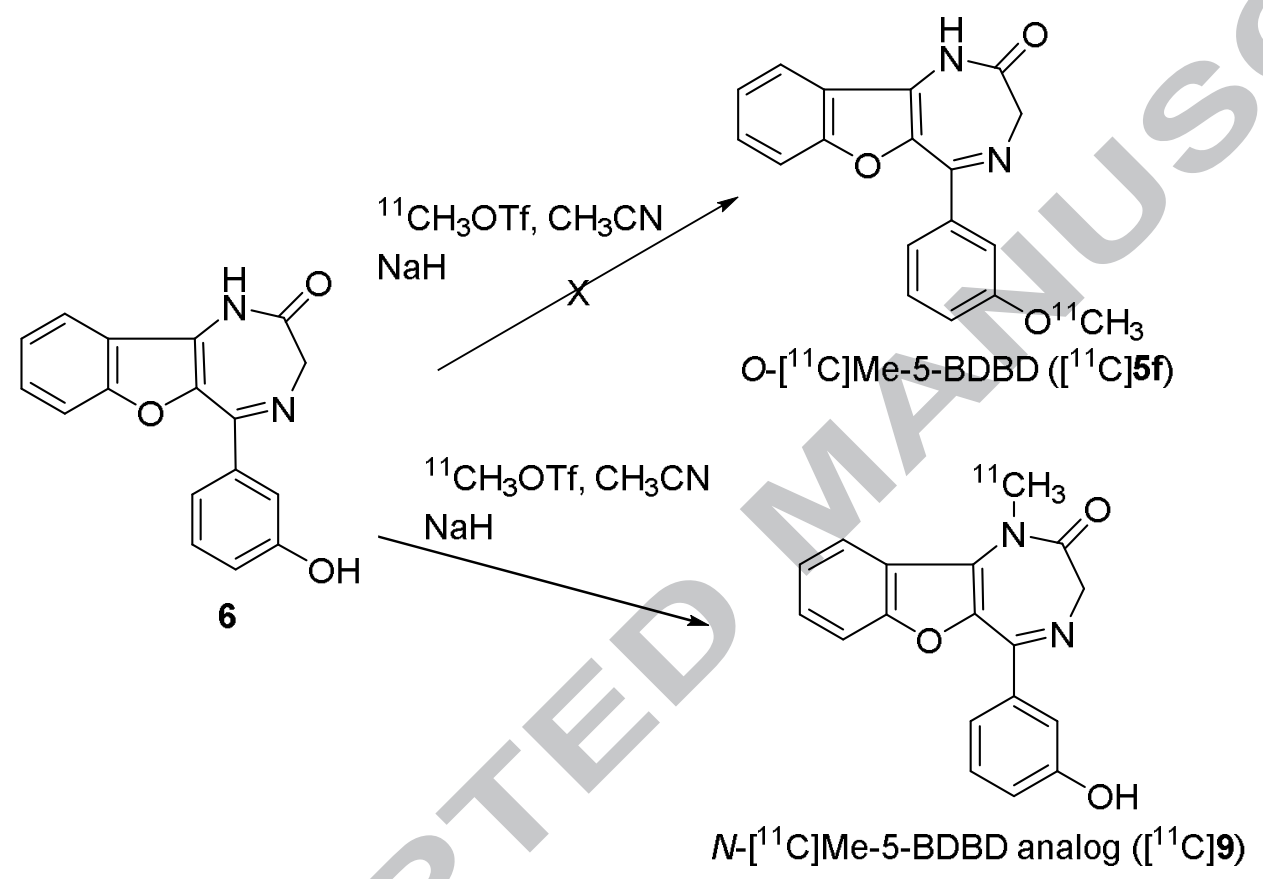

Scheme 3. Radiosynthesis of $N-\left[{ }^{11} \mathrm{C}\right] \mathrm{Me}-5-\mathrm{BDBD}$ analog $\left(\left[{ }^{11} \mathrm{C}\right] 9\right)$.

The precursor 6 underwent $\left[{ }^{11} \mathrm{C}\right]$ methylation ${ }^{17,18}$ using a reactive $\left[{ }^{11} \mathrm{C}\right]$ methylating agent $\left[{ }^{11} \mathrm{C}\right]$ methyl triflate $\left(\left[{ }^{11} \mathrm{C}\right] \mathrm{CH}_{3} \mathrm{OTf}\right){ }^{19,20}$ in acetonitrile at $80{ }^{\circ} \mathrm{C}$ under basic condition $(\mathrm{NaH})$ to obtain an unexpected radiolabeled product 5-(3-hydroxyphenyl)-1-[ $\left.{ }^{11} \mathrm{C}\right]$ methyl-1,3-dihydro-2Hbenzofuro[3,2-e][1,4]diazepin-2-one $\left(N-\left[{ }^{11} \mathrm{C}\right] \mathrm{Me}-5-\mathrm{BDBD}\right.$ analog, $\left.\left[{ }^{11} \mathrm{C}\right] 9\right) . \quad$ The expected radiolabeled product $O-\left[{ }^{11} \mathrm{C}\right] \mathrm{Me}-5-\mathrm{BDBD}\left(\left[{ }^{11} \mathrm{C}\right] \mathbf{5 f}\right)$ was not formed. For compound 6, its amide $\mathrm{N}-\mathrm{H}$ is more reactive than the phenol O-H. $\left[{ }^{11} \mathrm{C}\right]$ Methylation of the precursor 6 is outlined in 
Scheme 3. The product was isolated by semi-preparative reverse-phase (RP) high performance liquid chromatography (HPLC) with a C-18 column, and then concentrated by solid-phase extraction (SPE) ${ }^{21,22}$ with a disposable C-18 Light Sep-Pak cartridge to produce the corresponding pure radiolabeled compound $\left[{ }^{11} \mathrm{C}\right] 9$ in $30-50 \%$ radiochemical yield, decay corrected to end of bombardment (EOB), based on $\left[{ }^{11} \mathrm{C}_{\mathrm{CO}_{2}}\right.$. $\left[{ }^{11} \mathrm{C}\right] \mathrm{CH}_{3} \mathrm{OTf}$ is more reactive than commonly used $\left[{ }^{11} \mathrm{C}\right]$ methyl iodide $\left(\left[{ }^{11} \mathrm{C}\right] \mathrm{CH}_{3} \mathrm{I}\right)$, and we use $\left[{ }^{11} \mathrm{C}\right] \mathrm{CH}_{3} \mathrm{OTf}$ instead of $\left[{ }^{11} \mathrm{C}\right] \mathrm{CH}_{3} \mathrm{I}$ as the radiolabeled precursor to improve the radiochemical yield. ${ }^{17,18}$ Acetonitrile $\left(\mathrm{CH}_{3} \mathrm{CN}\right)$ was found to be an appropriate reaction solvent for $\left[{ }^{11} \mathrm{C}_{\mathrm{CH}_{3}} \mathrm{OTf}\right.$, and $\mathrm{N}, \mathrm{N}$-dimethylformamide (DMF) was found to be an inappropriate reaction solvent for $\left[{ }^{11} \mathrm{C}_{\mathrm{CH}_{3} \mathrm{OTf}}\right.$ since it reacted with and consumed a large portion of the radiolabel, especially under basic condition.

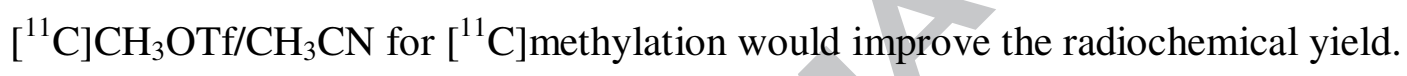

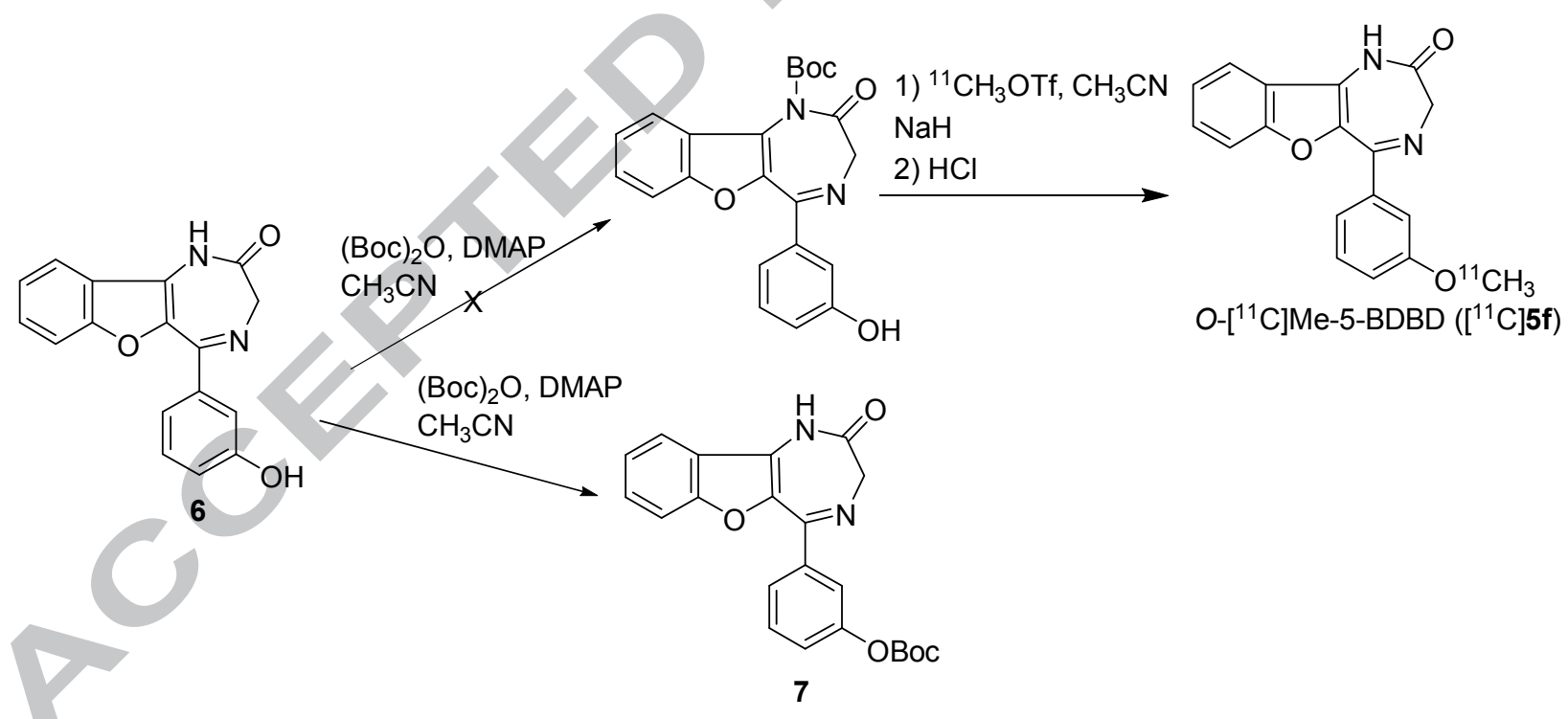

Scheme 4. The protecting reaction of 5-BDBD analog 6 with (Boc) $)_{2} \mathrm{O}$. 
As indicated in Scheme 4, in order to synthesize $O$ - $\left[{ }^{11} \mathrm{C}\right] \mathrm{Me}-5-\mathrm{BDBD}$, we attempted to protect the amide $\mathrm{N}-\mathrm{H}$ of $\mathbf{6}$ with tert-butyloxycarbonyl (Boc) protecting group using 4dimethylaminopyridine (DMAP) as a catalyst, ${ }^{5,23}$ but we only obtained a phenol O-H protected product 7 in $44 \%$ yield. The bulky Boc-group would react with the phenol O-H of $\mathbf{6}$, instead of the amide $\mathrm{N}-\mathrm{H}$, and the steric effect was involved.

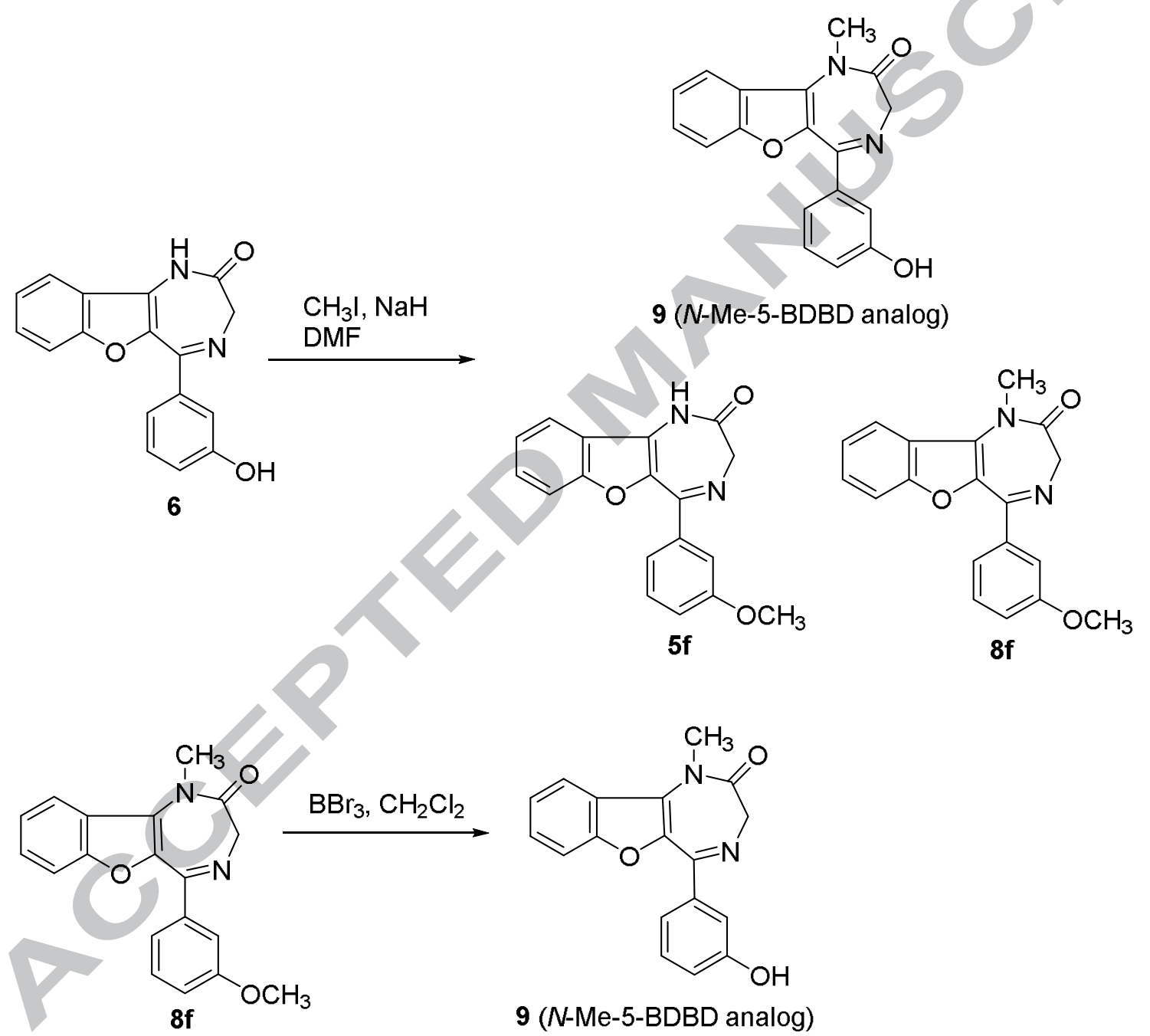

Scheme 5. Synthesis of $N$-Me-5-BDBD analog (9). 
Thus, we have no way to synthesize $O-\left[{ }^{11} \mathrm{C}\right] \mathrm{Me}-5-\mathrm{BDBD}$. Then, we have to synthesize the reference 5tandard 5-(3-hydroxyphenyl)-1-methyl-1,3-dihydro-2H-benzofuro[3,2e][1,4]diazepin-2-one (9) for $N-\left[{ }^{11} \mathrm{C}\right] \mathrm{Me}-5-\mathrm{BDBD}$ analog. As shown in Scheme 5, the direct methylation of $\mathbf{6}$ with $\mathrm{CH}_{3} \mathrm{I}$ in DMF provided a mixture containing $\mathbf{9}$, 5f, and $\mathbf{8 f}$. The reaction was monitored by thin layer chromatography (TLC). From TLC, only very little 9 was observed. In addition, it was difficult to purify the methylation mixture. Therefore, we conducted $O$ desmethylation ${ }^{14,15}$ of $\mathbf{8 f}$ with $\mathrm{BBr}_{3}$ in dichloromethane to afford $\mathbf{9}$ in $72 \%$ yield. $\mathrm{CH}_{3} \mathrm{I} / \mathrm{DMF}$ for methylation would improve the chemical yield.

The synthesis of 5-(3-bromophenyl)-1-[ $\left.{ }^{11} \mathrm{C}\right]$ methyl-1,3-dihydro- $2 H$-benzofuro[3,2$e][1,4]$ diazepin-2-one $\left(N-\left[{ }^{11} \mathrm{C}\right] \mathrm{Me}-5-\mathrm{BDBD},\left[{ }^{11} \mathrm{C}\right] \mathbf{8 c}\right)$ is depicted in Scheme 6. 5-BDBD was labeled with $\left[{ }^{11} \mathrm{C}\right] \mathrm{CH}_{3} \mathrm{OTf}$ through $N$ - $\left[{ }^{11} \mathrm{C}\right]$ Methylation ${ }^{24}$ under basic condition $(\mathrm{NaH})$ and isolated by HPLC-SPE method to give the target tracer $N-\left[{ }^{11} \mathrm{C}\right] \mathrm{Me}-5-\mathrm{BDBD}$ in $30-50 \%$ decay corrected radiochemical yield.

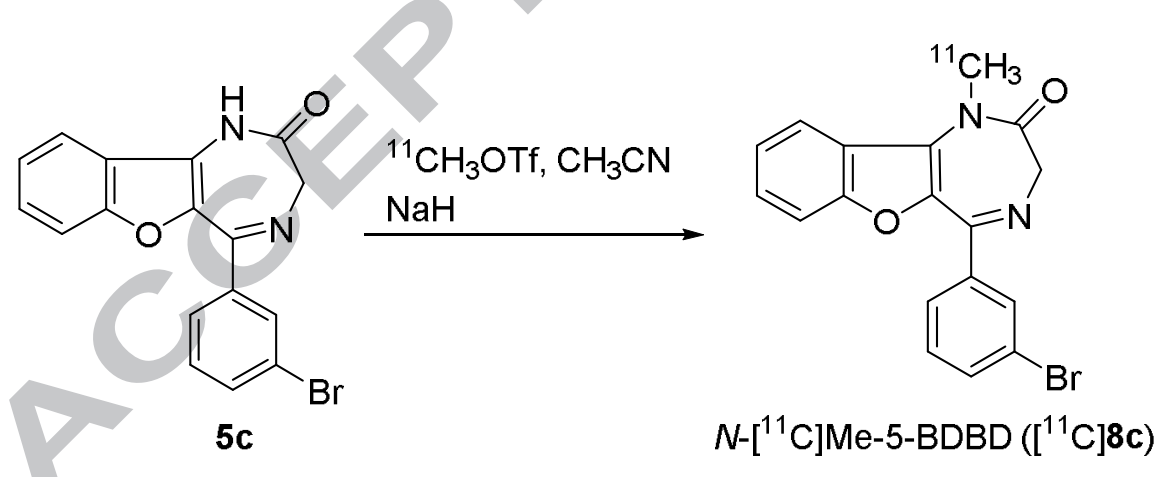

Scheme 6. Radiosynthesis of $N-\left[{ }^{11} \mathrm{C}\right] \mathrm{Me}-5-\mathrm{BDBD}\left(\left[{ }^{11} \mathrm{C}\right] \mathbf{8 c}\right)$. 
The ${ }^{11} \mathrm{C}$-radiosynthesis was performed in a home-built automated multipurpose $\left[{ }^{11} \mathrm{C}\right]-$ radiosynthesis module. ${ }^{25,26}$ It included three stages: 1) labeling reaction; 2) purification; and 3) formulation. We used a vial-method for reaction; semi-preparative HPLC for purification; and Light Sep-Pak trap/release for formulation. Overall, it took $\sim 40 \mathrm{~min}$ for synthesis, purification and dose formulation. Our $\left[{ }^{11} \mathrm{C}\right]$-radiosynthesis module is designed to allow in-process measurement of $\left[{ }^{11} \mathrm{C}\right]$-tracer specific activity $(\mathrm{SA}, \mathrm{GBq} / \mu \mathrm{mol}$ at $\mathrm{EOB})$ using a radiation detector at the outlet of the HPLC-portion of the system. For the reported syntheses, product SA was in a range of $370-1110 \mathrm{GBq} / \mu \mathrm{mol}$ at $\mathrm{EOB}$. The major factors including $\left[{ }^{11} \mathrm{C}\right]$-target and $\left[{ }^{11} \mathrm{C}\right]-$ radiosynthesis unit that affect the EOB SA significantly to lead to such a wide range from 370 to $1110 \mathrm{GBq} / \mu \mathrm{mol}$ have been discussed in our previous works. ${ }^{18}$ The general methods to increase SA have been described as well, and the SA of our $\left[{ }^{11} \mathrm{C}\right]$-tracers is significantly improved. ${ }^{18}$ The 'wide range' of SA we reported is for the same $\left[{ }^{11} \mathrm{C}\right]$-tracer produced in different days, because very different $\left[{ }^{11} \mathrm{C}\right]$-target and $\left[{ }^{11} \mathrm{C}\right]$-radiosynthesis unit situations would make $\mathrm{SA}$ in a wide range. For a $\left[{ }^{11} \mathrm{C}\right]$-tracer produced in the same day, the SA of the same tracer in different production runs will be in a small range, because $\left[{ }^{11} \mathrm{C}\right]$-target and $\left[{ }^{11} \mathrm{C}\right]$-radiosynthesis unit would not be much different in the same day. Likewise, the methods to minimize such wide range of SA from practice perspective have been provided in our previous works. ${ }^{18}$ At the end of synthesis (EOS), the SA of $\left[{ }^{11} \mathrm{C}\right]$-tracer was actually determined again by analytical HPLC, ${ }^{27}$ calculated, decay corrected to $\mathrm{EOB}$, and based on $\left[{ }^{11} \mathrm{C}\right] \mathrm{CO}_{2}$, which was in agreement with the 'on line' determined value. In each our $\left[{ }^{11} \mathrm{C}\right]$-tracer production, if semi-preparative HPLC was used for purification, then the SA of $\left[{ }^{11} \mathrm{C}\right]$-tracer was assessed by both semi-preparative HPLC (during synthesis) and analytical HPLC (EOS). 

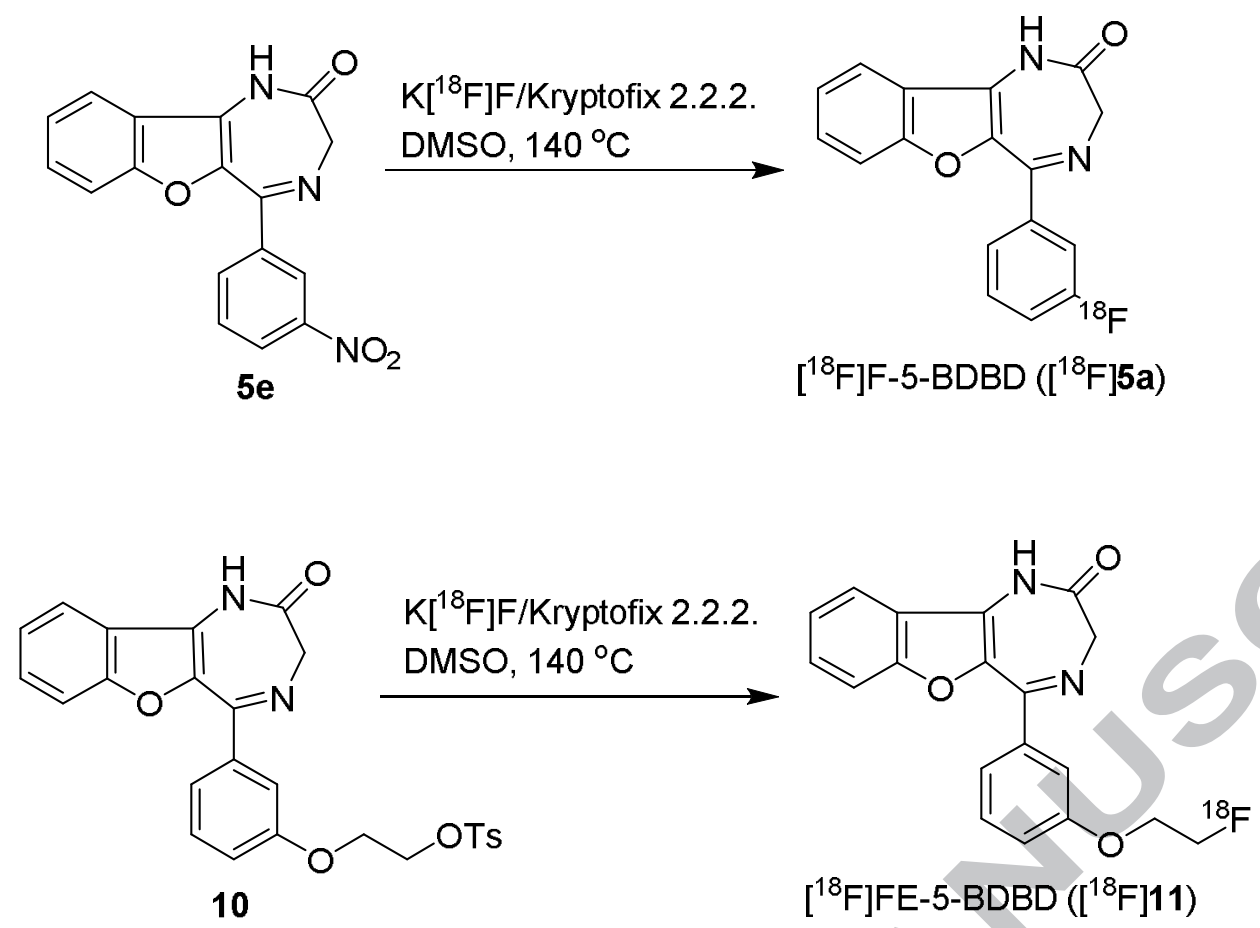

$\left[{ }^{18} \mathrm{~F}\right] \mathrm{FE}-5-\mathrm{BDBD}\left(\left[{ }^{18} \mathrm{~F}\right] 11\right)$

Scheme 7. Radiosynthesis of $\left[{ }^{18} \mathrm{~F}\right] \mathrm{F}-5-\mathrm{BDBD}\left(\left[{ }^{18} \mathrm{~F}\right] \mathbf{5 a}\right)$ and $\left[{ }^{18} \mathrm{~F}\right] \mathrm{FE}-5-\mathrm{BDBD}\left(\left[{ }^{18} \mathrm{~F}\right] \mathbf{1 1}\right)$.

As shown in Scheme 7, the nitro-precursor 5e was labeled with $\mathrm{K}\left[{ }^{18} \mathrm{~F}\right] \mathrm{F} / \mathrm{Kryptofix} 2.2 .2$ through nucleophilic substitution ${ }^{28}$ and isolated by the HPLC-SPE method to produce the corresponding radiolabeled product $5-\left(3-\left[{ }^{18}\right.\right.$ F]fluorophenyl)-1,3-dihydro-2H-benzofuro[3,2-e $][1,4]$ diazepin-2one $\left(\left[{ }^{18} \mathrm{~F}\right] \mathrm{F}-5-\mathrm{BDBD},\left[{ }^{18} \mathrm{~F}\right] \mathbf{5 a}\right)$ in $5-15 \%$ decay corrected radiochemical yield from $\mathrm{K}\left[{ }^{18} \mathrm{~F}\right] \mathrm{F}$ at EOB. Likewise, the tosylated precursor $\mathbf{1 0}$ was labeled with $\mathrm{K}\left[{ }^{18} \mathrm{~F}\right] \mathrm{F} /$ Kryptofix $2.2 .2^{29}$ and isolated by HPLC-SPE to produce the corresponding radiolabeled product 5-(3-(2$\left[{ }^{18} \mathrm{~F}\right]$ fluoroethoxy)phenyl)-1,3-dihydro-2 $H$-benzofuro[3,2-e $][1,4]$ diazepin-2-one $\quad\left(\left[{ }^{18} \mathrm{~F}\right] \mathrm{FE}-5\right.$ BDBD, $\left.\left[{ }^{18} \mathrm{~F}\right] \mathbf{1 1}\right)$ in $15-25 \%$ decay corrected radiochemical yield. Using dimethyl sulfoxide (DMSO) as the reaction solvent and running radiolabelling reaction at $140{ }^{\circ} \mathrm{C}$ would increase the radiochemical yield. ${ }^{30}$ The effect of the reaction solvent and temperature on the radiochemical 
yield has been studied in our previous work by direct comparison of DMSO/140 ${ }^{\circ} \mathrm{C}$ with $\mathrm{CH}_{3} \mathrm{CN} / 120{ }^{\circ} \mathrm{C} .{ }^{29}$

The ${ }^{18} \mathrm{~F}$-radiosynthesis was performed in an automated multipurpose $\left[{ }^{18} \mathrm{~F}\right]$-radiosynthesis module of our own design. ${ }^{16}$ The radiosynthesis process included labeling reaction, purification and formulation. The overall synthesis, purification and formulation time was $\sim 70$ min from EOB. The SA of $\left[{ }^{18} \mathrm{~F}\right]$-tracer can be assessed by both semi-preparative HPLC (during synthesis) and analytical HPLC (EOS). ${ }^{27}{ }^{18} \mathrm{~F}$-product SA was in a range of $111-740 \mathrm{GBq} / \mu \mathrm{mol}$ at EOB.

Chemical purity and radiochemical purity were determined by analytical HPLC. ${ }^{27}$ The chemical purity of the precursors $(\mathbf{6}, \mathbf{5 c}, \mathbf{5 e}$, and $\mathbf{1 0})$ and reference standards $(\mathbf{9}, \mathbf{8 c}, \mathbf{5 a}$, and $\mathbf{1 1})$ was $>90 \%$. The radiochemical purity of the target tracers $\left(\left[{ }^{11} \mathrm{C}\right] \mathbf{9},\left[{ }^{11} \mathrm{C}\right] \mathbf{8 c},\left[{ }^{18} \mathrm{~F}\right] \mathbf{5 a}\right.$, and $\left.\left[{ }^{18} \mathrm{~F}\right] \mathbf{1 1}\right)$ was $>99 \%$ determined by radio-HPLC through $\gamma$-ray (PIN diode) flow detector, and the chemical purity of the target tracers was $>90 \%$ determined by reversed-phase HPLC through UV flow detector.

\subsection{In vitro binding studies}

The preliminary biological evaluation of the carbon-11 radioligands $\left[{ }^{11} \mathrm{C}\right] \mathbf{9}$ and $\left[{ }^{11} \mathrm{C}\right] \mathbf{8 c}$ was performed by a radioligand depletion experiment. ${ }^{6,31}$ In this experiment, a wide range of protein was used for the optimization of the assay conditions. For the law of mass action to be valid, the protein and radioligand concentration need to be at levels where no more than $10 \%$ of the total radioligand added is bound to the protein. Otherwise the radioligand is considered depleted and specialized formulas for radioligand depletion must be used for analysis of the data in saturation 
or competitive binding assays. An optimized binding assay uses protein levels where the radioligand is depleted no more than $10 \%$, and where sufficient signal to background binding levels, at least 5 fold total binding/non-specific binding ratio, are obtained. To achieve both of these ends, a wide range of membrane protein concentrations was tested to get the optimal level for the assay. The results indicated low affinity of $\left[{ }^{11} \mathrm{C}\right] \mathbf{9}$ and $\left[{ }^{11} \mathrm{C}\right] \mathbf{8 c}$ to $\mathrm{P} 2 \mathrm{X} 4$ receptor. We suspected the radioligands might be too sticky. Then the method was further optimized by improving the solubility of the tracers $\left[{ }^{11} \mathrm{C}\right] \mathbf{9}$ and $\left[{ }^{11} \mathrm{C}\right] \mathbf{8 c}$, and the results remained same. Thus the competitive binding assay of ligands 5-BDBD (5c), $N$-Me-5-BDBD (8c), N-Me-5-BDBD analog (9), F-5-BDBD (5a) and FE-5-BDBD (11) was conducted following the literature method ${ }^{31,32}$ with modifications using $\left[{ }^{35} \mathrm{~S}\right] \mathrm{ATP} \gamma \mathrm{S}$ as the radioligand, ATP as a positive control, and buffer as a negative control, respectively. The assays were incubated at $4{ }^{\circ} \mathrm{C}$ for $2 \mathrm{~h}$. The results are shown in Figure 3, which showed new ligands we synthesized have similar biological activity in comparison with the parent compound 5-BDBD, because their binding curves are similar. These results suggest more potent PET P2X4 receptor radioligands remain to be discovered and developed.
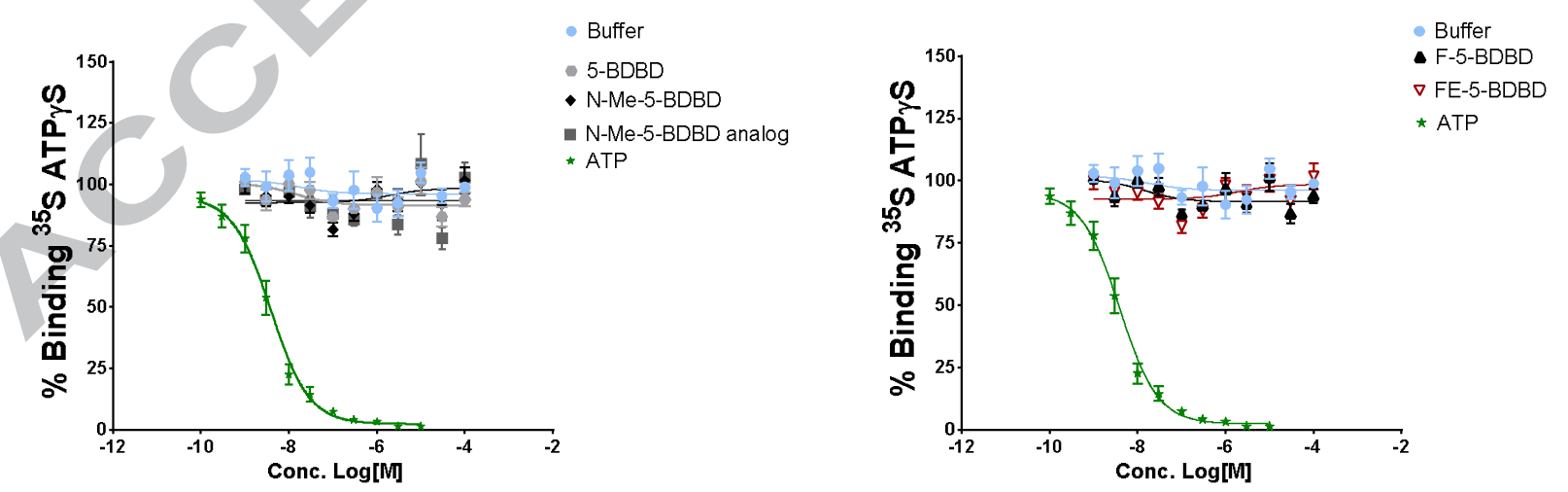

Figure 3. The results of the ligand competitive binding assay of 5-BDBD analogs. 


\section{Materials and methods}

\subsection{General}

All commercial reagents and solvents were purchased from Sigma-Aldrich and Fisher Scientific, and used without further purification. $\left[{ }^{11} \mathrm{C}\right] \mathrm{CH}_{3} \mathrm{OTf}$ was prepared according to a literature procedure. $^{20}$ Melting points were determined on a MEL-TEMP II capillary tube apparatus and were uncorrected. ${ }^{1} \mathrm{H}$ and ${ }^{13} \mathrm{C}$ NMR spectra were recorded on a Bruker Avance II $500 \mathrm{MHz}$ NMR Fourier transform spectrometer at 500 and $125 \mathrm{MHz}$, respectively. Chemical shifts $(\delta)$ are reported in parts per million ( $\mathrm{ppm}$ ) relative to an internal standard tetramethylsilane (TMS, $\delta 0.0)$ $\left({ }^{1} \mathrm{H}\right.$ NMR) and to the solvent signal $\left({ }^{13} \mathrm{C}\right.$ NMR $)$, and coupling constants $(J)$ are reported in hertz (Hz). Liquid chromatography-mass spectra (LC-MS) analysis was performed on an Agilent system, consisting of an 1100 series HPLC connected to a diode array detector and a 1946D mass spectrometer configured for positive-ion/negative-ion electrospray ionization. The high resolution mass spectra (HRMS) were obtained using a Waters/Micromass LCT Classic spectrometer. Chromatographic solvent proportions are indicated as volume: volume ratio. TLC was run using Analtech silica gel GF uniplates $\left(5 \times 10 \mathrm{~cm}^{2}\right)$. Plates were visualized under UV light. Preparative TLC was run using Analtech silica gel UV254 plates $\left(20 \times 20 \mathrm{~cm}^{2}\right)$. Normal phase flash column chromatography was carried out on EM Science silica gel 60 (230-400 mesh) with a forced flow of the indicated solvent system in the proportions described below. All moisture- and air-sensitive reactions were performed under a positive pressure of nitrogen 
maintained by a direct line from a nitrogen source. C18 Sep-Pak Light and Plus cartridges were obtained from Waters Corporation (Milford, MA). Sterile Millex-FG 0.2 $\mu \mathrm{m}$ filter units were obtained from Millipore Corporation (Bedford, MA).

\subsection{2-Bromo-1-(3-iodophenyl)ethanone (1d)}

To a stirred solution of 3-iodoacetophenone $(5.0 \mathrm{~g}, 20.3 \mathrm{mmol})$ in $\mathrm{EtOAc} / \mathrm{CHCl}_{3}(100 \mathrm{~mL} / 100$ mL) was added $\mathrm{CuBr}_{2}(9.1 \mathrm{~g}, 40.6 \mathrm{mmol})$. After the reaction mixture was heated under reflux for $3.5 \mathrm{~h}$, it was cooled and filtered through Celite. The solvent was evaporated in vacuo to afford 1d as a white solid $(4.4 \mathrm{~g}, 67 \%)$, which was used for next step without further purification. ${ }^{1} \mathrm{H}$ NMR $\left(\mathrm{DMSO}-d_{6}\right): \delta 8.30(\mathrm{t}, J=2.0 \mathrm{~Hz}, 1 \mathrm{H}), 8.04(\mathrm{dt}, J=1.0,8.0 \mathrm{~Hz}, 1 \mathrm{H}), 8.00(\mathrm{dt}, J=1.0,8.0 \mathrm{~Hz}$, 1H), $7.37(\mathrm{t}, J=8.0 \mathrm{~Hz}, 1 \mathrm{H}), 4.96(\mathrm{~s}, 2 \mathrm{H})$.

\subsection{General procedure for preparation of compound $\mathbf{3}$}

(3-Aminobenzofuran-2-yl)-(3-fluorophenyl)methanone (3a). A mixture of 2-hydroxybenzonitrile (1.0 g, $8.4 \mathrm{mmol}$ ), 2-bromo-1-(3-fluorophenyl)ethanone (1a, $2.0 \mathrm{~g}, 9.2 \mathrm{mmol}$ ) and $\mathrm{Na}_{2} \mathrm{CO}_{3}$ $(1.33 \mathrm{~g}, 12.6 \mathrm{mmol})$ in anhydrous DMF $(15 \mathrm{~mL})$ was stirred at room temperature (RT) overnight. The reaction mixture was poured into water. The precipitate was collected by filtration and washed with water. The solid was dissolved in EtOAc, washed with brine, dried over anhydrous $\mathrm{MgSO}_{4}$, and filtered. After the solvent was evaporated in vacuo, $\mathrm{MeOH}(25 \mathrm{~mL})$ was added to the intermediate solid, followed by addition of sodium methoxide (463 mg, $8.6 \mathrm{mmol}$ ). The reaction mixture was stirred and heated under reflux for $30 \mathrm{~min}$. The mixture was cooled and 
pour into ice-water. The precipitate was collected by filtration and washed with water. The solid was dried in vacuo to afford $3 \mathbf{a}$ as a yellow solid $(2.0 \mathrm{~g}, 91 \%)$; mp $126-128{ }^{\circ} \mathrm{C} .{ }^{1} \mathrm{H}$ NMR $\left(\mathrm{DMSO}-d_{6}\right): \delta 8.08(\mathrm{~d}, J=8.0 \mathrm{~Hz}, 1 \mathrm{H}), 7.99(\mathrm{~d}, J=7.5 \mathrm{~Hz}, 1 \mathrm{H}), 7.86-7.84(\mathrm{~m}, 1 \mathrm{H}), 7.66-7.57$ (m, 5H), 7.48-7.45 (m, 1H), 7.34-7.30 (m, 1H).

(3-Aminobenzofuran-2-yl)-(3-chlorophenyl)methanone (3b). Compound $\mathbf{3 b}$ was prepared with similar procedure as compound 3a from 1b. Yield: $82 \%$, yellow solid; mp 122-124 ${ }^{\circ} \mathrm{C} .{ }^{1} \mathrm{H}$ NMR (DMSO- $\left.d_{6}\right): \delta 8.09-8.06(\mathrm{~m}, 3 \mathrm{H}), 7.69-7.67(\mathrm{~m}, 1 \mathrm{H}), 7.62-7.56(\mathrm{~m}, 5 \mathrm{H}), 7.33-7.30(\mathrm{~m}, 1 \mathrm{H})$.

(3-Aminobenzofuran-2-yl)-(3-bromophenyl)methanone (3c). Compound $\mathbf{3 c}$ was prepared with similar procedure as compound 3a from 1c. Yield: $87 \%$, yellow solid; mp 102-104 ${ }^{\circ} \mathrm{C} .{ }^{1} \mathrm{H}$ NMR $\left(\mathrm{DMSO}-d_{6}\right): \delta 8.19(\mathrm{t}, J=2.0 \mathrm{~Hz}, 1 \mathrm{H}), 8.13(\mathrm{dt}, J=1.0,8.0 \mathrm{~Hz}, 1 \mathrm{H}), 8.08(\mathrm{~d}, J=8.0 \mathrm{~Hz}, 1 \mathrm{H})$, 7.82-7.80 (m, 1H), 7.61-7.53 (m, 5H), 7.33-7.30 (m, 1H).

(3-Aminobenzofuran-2-yl)-(3-iodophenyl)methanone (3d). Compound 3d was prepared with similar procedure as compound 3a from 1d. Yield: $88 \%$, yellow solid; mp $138-140{ }^{\circ} \mathrm{C} .{ }^{1} \mathrm{H}$ NMR $\left(\mathrm{DMSO}-d_{6}\right): \delta 8.35(\mathrm{t}, J=1.5 \mathrm{~Hz}, 1 \mathrm{H}), 8.14(\mathrm{~d}, J=8.0 \mathrm{~Hz}, 1 \mathrm{H}), 8.07(\mathrm{~d}, J=8.0 \mathrm{~Hz}, 1 \mathrm{H}), 7.97-$ $7.96(\mathrm{~m}, 1 \mathrm{H}), 7.60-7.54(\mathrm{~m}, 4 \mathrm{H}), 7.39(\mathrm{t}, J=8.0 \mathrm{~Hz}, 1 \mathrm{H}), 7.33-7.30(\mathrm{~m}, 1 \mathrm{H})$.

(3-Aminobenzofuran-2-yl)-(3-nitrophenyl)methanone (3e). Compound $\mathbf{3 e}$ was prepared with similar procedure as compound 3a from 1e. Yield: $84 \%$, yellow solid; mp $166-168{ }^{\circ} \mathrm{C} .{ }^{1} \mathrm{H}$ NMR $\left(\mathrm{DMSO}-d_{6}\right): \delta 8.85(\mathrm{t}, J=2.0 \mathrm{~Hz}, 1 \mathrm{H}), 8.56(\mathrm{~d}, J=7.5 \mathrm{~Hz}, 1 \mathrm{H}), 8.46-8.44(\mathrm{~m}, 1 \mathrm{H}), 8.11(\mathrm{~d}, J=$ $8.0 \mathrm{~Hz}, 1 \mathrm{H}), 7.88(\mathrm{t}, J=8.0 \mathrm{~Hz}, 1 \mathrm{H}), 7.72(\mathrm{br} \mathrm{s}, 2 \mathrm{H}), 7.63-7.60(\mathrm{~m}, 1 \mathrm{H}), 7.56(\mathrm{~d}, J=8.0 \mathrm{~Hz}, 1 \mathrm{H})$, $7.35-7.32(\mathrm{~m}, 1 \mathrm{H})$.

(3-Aminobenzofuran-2-yl)-(3-methoxyphenyl)methanone (3f). Compound $\mathbf{3 f}$ was prepared with similar procedure as compound 3a from 1f. Yield: $98 \%$, yellow solid; mp 126-128 ${ }^{\circ} \mathrm{C} .{ }^{1} \mathrm{H}$ NMR 
(DMSO- $\left.d_{6}\right): \delta 8.07(\mathrm{~d}, J=7.5 \mathrm{~Hz}, 1 \mathrm{H}), 7.73(\mathrm{~d}, J=7.5 \mathrm{~Hz}, 1 \mathrm{H}), 7.61$ (br s, $\left.1 \mathrm{H}\right), 7.58-7.48(\mathrm{~m}$, 5H), 7.33-7.30 (m, 1H), $7.18(\mathrm{dd}, J=2.0,8.0 \mathrm{~Hz}, 1 \mathrm{H})$.

\subsection{General procedure for preparation of compound 4}

2-Bromo-N-(2-(3-fluorobenzoyl)benzofuran-3-yl)acetamide (4a). To a stirred mixture of compound 3a $(1.4 \mathrm{~g}, 5.3 \mathrm{mmol})$ and $\mathrm{NaHCO}_{3}(1.8 \mathrm{~g}, 51.3 \mathrm{mmol})$ in $\mathrm{CHCl}_{3}(25 \mathrm{~mL})$ was added bromoacetyl bromide $(0.6 \mathrm{~mL}, 6.9 \mathrm{mmol})$ dropwise at $0{ }^{\circ} \mathrm{C}$. The reaction mixture was stirred at 0 ${ }^{\circ} \mathrm{C}$ for $1.5 \mathrm{~h}$. After the solvent was evaporated in vacuo, EtOAc was added to dissolve the residue. The organic solution was washed with saturated aqueous $\mathrm{NaHCO}_{3}$ and brine, dried over anhydrous $\mathrm{Na}_{2} \mathrm{SO}_{4}$, and filtered. The solvent was evaporated in vacuo. The crude product was washed with hexanes and $\mathrm{Et}_{2} \mathrm{O}$ to afford $4 \mathbf{a}$ as a yellow solid $(1.8 \mathrm{~g}, 89 \%)$; mp 106-108 ${ }^{\circ} \mathrm{C} .{ }^{1} \mathrm{H}$ NMR (DMSO-d $\left.)_{6}\right): \delta 10.90(\mathrm{~s}, 1 \mathrm{H}), 7.98(\mathrm{~d}, J=8.0 \mathrm{~Hz}, 1 \mathrm{H}), 7.88-7.86(\mathrm{~m}, 1 \mathrm{H}), 7.79-7.75(\mathrm{~m}$, 2H), 7.68-7.61 (m, 2H), 7.57-7.54 (m, 1H), 7.43-7.40 (m, 1H), $4.23(\mathrm{~s}, 2 \mathrm{H})$.

2-Bromo-N-(2-(3-chlorobenzoyl)benzofuran-3-yl)acetamide (4b). Compound $\mathbf{4 b}$ was prepared with similar procedure as compound $\mathbf{4 a}$ from 3b. Yield: $75 \%$, pale yellow solid; mp 112-114 ${ }^{\circ} \mathrm{C}$. ${ }^{1} \mathrm{H}$ NMR (DMSO- $\left.d_{6}\right): \delta 10.90(\mathrm{~s}, 1 \mathrm{H}), 7.98-7.95(\mathrm{~m}, 3 \mathrm{H}), 7.77-7.74(\mathrm{~m}, 2 \mathrm{H}), 7.64-7.61(\mathrm{~m}, 2 \mathrm{H})$, 7.43-7.40 (m, 1H), $4.21(\mathrm{~s}, 2 \mathrm{H})$.

2-Bromo-N-(2-(3-bromobenzoyl)benzofuran-3-yl)acetamide (4c). Compound 4c was prepared with similar procedure as compound 4a from 3c. Yield: $78 \%$, yellow solid; mp $118-120{ }^{\circ} \mathrm{C} .{ }^{1} \mathrm{H}$ NMR (DMSO-d $\left.d_{6}\right): \delta 10.89(\mathrm{~s}, 1 \mathrm{H}), 8.08(\mathrm{t}, J=2.0 \mathrm{~Hz}, 1 \mathrm{H}), 8.00(\mathrm{dt}, J=1.0,7.5 \mathrm{~Hz}, 1 \mathrm{H}), 7.97$ $(\mathrm{d}, J=8.0 \mathrm{~Hz}, 1 \mathrm{H}), 7.90-7.88(\mathrm{~m}, 1 \mathrm{H}), 7.75(\mathrm{~d}, J=8.5 \mathrm{~Hz}, 1 \mathrm{H}), 7.64-7.60(\mathrm{~m}, 1 \mathrm{H}), 7.56(\mathrm{t}, J=$ 8.0 Hz, 1H), 7.43-7.40 (m, 1H), $4.21(\mathrm{~s}, 2 \mathrm{H})$. 
2-Bromo-N-(2-(3-iodobenzoyl)benzofuran-3-yl)acetamide (4d). Compound $\mathbf{4 d}$ was prepared with similar procedure as compound $4 \mathbf{a}$ from 3d. Yield: 88\%, yellow solid; mp 140-142 ${ }^{\circ} \mathrm{C} .{ }^{1} \mathrm{H}$ NMR (DMSO- $\left.d_{6}\right): \delta 10.88(\mathrm{~s}, 1 \mathrm{H}), 8.23(\mathrm{t}, J=1.5 \mathrm{~Hz}, 1 \mathrm{H}), 8.06-8.04(\mathrm{~m}, 1 \mathrm{H}), 8.01(\mathrm{dt}, J=1.5,7.5$ $\mathrm{Hz}, 1 \mathrm{H}), 7.97(\mathrm{~d}, J=8.0 \mathrm{~Hz}, 1 \mathrm{H}), 7.74(\mathrm{~d}, J=8.0 \mathrm{~Hz}, 1 \mathrm{H}), 7.64-7.60(\mathrm{~m}, 1 \mathrm{H}), 7.43-7.38(\mathrm{~m}$, $2 \mathrm{H}), 4.21(\mathrm{~s}, 2 \mathrm{H})$.

2-Bromo-N-(2-(3-nitrobenzoyl)benzofuran-3-yl)acetamide (4e). Compound $4 \mathbf{e}$ was prepared with similar procedure as compound $4 \mathbf{a}$ from 3e. Yield: $87 \%$, yellow solid; mp 150-152 ${ }^{\circ} \mathrm{C} .{ }^{1} \mathrm{H}$ NMR (DMSO- $\left.d_{6}\right): \delta 10.96(\mathrm{~s}, 1 \mathrm{H}), 8.66(\mathrm{t}, J=2.0 \mathrm{~Hz}, 1 \mathrm{H}), 8.52-8.50(\mathrm{~m}, 1 \mathrm{H}), 8.41(\mathrm{dt}, J=1.0,8.0$ $\mathrm{Hz}, 1 \mathrm{H}), 7.99(\mathrm{~d}, J=8.0 \mathrm{~Hz}, 1 \mathrm{H}), 7.89(\mathrm{t}, J=8.0 \mathrm{~Hz}, 1 \mathrm{H}), 7.76(\mathrm{~d}, J=8.0 \mathrm{~Hz}, 1 \mathrm{H}), 7.66-7.63$ (m, 1H), 7.46-7.42 (m, 1H), $4.16(\mathrm{~s}, 2 \mathrm{H})$.

2-Bromo-N-(2-(3-methoxybenzoyl)benzofuran-3-yl)acetamide (4f). Compound $\mathbf{4 f}$ was prepared with similar procedure as compound $4 \mathbf{4 a}$ from 3 f. Yield: $87 \%$, yellow solid; mp $122-124{ }^{\circ} \mathrm{C} .{ }^{1} \mathrm{H}$ NMR (DMSO- $\left.d_{6}\right): \delta 10.88(\mathrm{~s}, 1 \mathrm{H}), 7.98(\mathrm{~d}, J=8.0 \mathrm{~Hz}, 1 \mathrm{H}), 7.75(\mathrm{~d}, J=7.5 \mathrm{~Hz}, 1 \mathrm{H}), 7.64-7.60$ $(\mathrm{m}, 2 \mathrm{H}), 7.54-7.51(\mathrm{~m}, 2 \mathrm{H}), 7.41(\mathrm{t}, J=7.5 \mathrm{~Hz}, 1 \mathrm{H}), 7.28(\mathrm{dd}, J=2.5,8.5 \mathrm{~Hz}, 1 \mathrm{H}), 4.24(\mathrm{~s}, 2 \mathrm{H})$ $3.85(\mathrm{~s}, 3 \mathrm{H})$.

\subsection{General procedure for preparation of compound 5}

5-(3-Fluorophenyl)-1,3-dihydro-2H-benzofuro[3,2-e][1,4]diazepin-2-one (F-5-BDBD, 5a). To a stirred compound $4 \mathbf{a}(1.0 \mathrm{~g}, 2.7 \mathrm{mmol})$ in dioxane $(5 \mathrm{~mL})$ was added ammonia $(0.5 \mathrm{M}$ solution in dioxane, $60 \mathrm{~mL}, 30.0 \mathrm{mmol}$ ). After the reaction mixture was stirred at RT for 2 days, EtOAc was added. The mixture was washed with water, brine, dried over anhydrous $\mathrm{Na}_{2} \mathrm{SO}_{4}$ and filtered. The solvent was evaporated in vacuo. The crude product was washed with $\mathrm{MeOH}$ to afford $\mathbf{5 a}$ as 
a pale yellow solid $(724 \mathrm{mg}, 92 \%) ; \mathrm{mp} 256-258{ }^{\circ} \mathrm{C} .{ }^{1} \mathrm{H}$ NMR (DMSO- $\left.d_{6}\right): \delta 11.60(\mathrm{~s}, 1 \mathrm{H}), 8.00$ $(\mathrm{d}, J=7.5 \mathrm{~Hz}, 1 \mathrm{H}), 7.70(\mathrm{~d}, J=8.5 \mathrm{~Hz}, 1 \mathrm{H}), 7.61-7.53(\mathrm{~m}, 4 \mathrm{H}), 7.44-7.39(\mathrm{~m}, 2 \mathrm{H}), 4.46(\mathrm{~s}, 2 \mathrm{H})$. ${ }^{13} \mathrm{C}$ NMR (DMSO- $\left.d_{6}\right): \delta 165.7,162.9,161.0(\mathrm{~d}, J=122 \mathrm{~Hz}), 153.6,138.3,130.4,129.0,128.6$, 125.2, 123.5, 120.8, 120.7, 117.5, 115.4, 112.4, 59.2. HRMS (ESI, $m / z)$ : Calcd for $\mathrm{C}_{17} \mathrm{H}_{12} \mathrm{FN}_{2} \mathrm{O}_{2}$ $\left([\mathrm{M}+\mathrm{H}]^{+}\right)$295.0883, found: 295.0883 .

5-(3-Chlorophenyl)-1,3-dihydro-2H-benzofuro[3,2-e][1,4]diazepin-2-one (5b). Compound $\mathbf{5 b}$ was prepared with similar procedure as compound 5a from 4b. Yield: 62\%, pale yellow solid; mp 263-264 ${ }^{\circ} \mathrm{C} .{ }^{1} \mathrm{H}$ NMR (DMSO- $\left.d_{6}\right): \delta 11.59(\mathrm{~s}, 1 \mathrm{H}), 8.00(\mathrm{~d}, J=7.5 \mathrm{~Hz}, 1 \mathrm{H}), 7.77(\mathrm{t}, J=2.0$ $\mathrm{Hz}, 1 \mathrm{H}), 7.72-7.70(\mathrm{~m}, 2 \mathrm{H}), 7.63-7.61(\mathrm{~m}, 1 \mathrm{H}), 7.60-7.56(\mathrm{~m}, 1 \mathrm{H}), 7.53(\mathrm{t}, J=8.0 \mathrm{~Hz}, 1 \mathrm{H}), 7.44-$ $7.41(\mathrm{~m}, 1 \mathrm{H}), 4.46(\mathrm{~s}, 2 \mathrm{H}) .{ }^{13} \mathrm{C}$ NMR $\left(\mathrm{DMSO}-d_{6}\right): \delta 165.7,160.0,153.6,138.2,138.0,133.2$, $130.4,130.3,129.0,128.6,128.4,127.7,123.5,120.8,120.7,112.4,59.2$. HRMS (ESI, $m / z)$ : Calcd for $\mathrm{C}_{17} \mathrm{H}_{12} \mathrm{ClN}_{2} \mathrm{O}_{2}\left([\mathrm{M}+\mathrm{H}]^{+}\right)$311.0587, found: 311.0573 .

5-(3-Bromophenyl)-1,3-dihydro-2H-benzofuro[3,2-e][1,4]diazepin-2-one $\quad(5-B D B D, \quad 5 \mathrm{c})$. Compound $\mathbf{5 c}$ was prepared with similar procedure as compound $\mathbf{5 a}$ from $\mathbf{4 c}$. Yield: $84 \%$, pale yellow solid; mp $244-246{ }^{\circ} \mathrm{C} .{ }^{1} \mathrm{H}$ NMR (DMSO-d $\left.d_{6}\right): \delta 11.59(\mathrm{~s}, 1 \mathrm{H}), 8.00(\mathrm{~d}, J=7.5 \mathrm{~Hz}, 1 \mathrm{H})$, $7.91(\mathrm{~s}, 1 \mathrm{H}), 7.76-7.73(\mathrm{~m}, 2 \mathrm{H}), 7.70(\mathrm{~d}, J=8.0 \mathrm{~Hz}, 1 \mathrm{H}), 7.59-7.56(\mathrm{~m}, 1 \mathrm{H}), 7.47(\mathrm{t}, J=8.0 \mathrm{~Hz}$, $1 \mathrm{H}), 7.43(\mathrm{t}, J=7.5 \mathrm{~Hz}, 1 \mathrm{H}), 4.46(\mathrm{~s}, 2 \mathrm{H})$.

5-(3-Iodophenyl)-1,3-dihydro-2H-benzofuro[3,2-e][1,4]diazepin-2-one (5d). Compound 5d was prepared with similar procedure as compound 5a from 4d. Yield: 58\%, pale yellow solid; mp 245-246 ${ }^{\circ} \mathrm{C} .{ }^{1} \mathrm{H}$ NMR (DMSO- $\left.d_{6}\right): \delta 11.58(\mathrm{~s}, 1 \mathrm{H}), 8.08(\mathrm{t}, J=1.5 \mathrm{~Hz}, 1 \mathrm{H}), 8.00(\mathrm{~d}, J=8.0 \mathrm{~Hz}$, $1 \mathrm{H}), 7.91(\mathrm{~d}, J=8.0 \mathrm{~Hz}, 1 \mathrm{H}), 7.74(\mathrm{~d}, J=8.0 \mathrm{~Hz}, 1 \mathrm{H}), 7.70(\mathrm{~d}, J=8.5 \mathrm{~Hz}, 1 \mathrm{H}), 7.59-7.56(\mathrm{~m}$, 1H), $7.43(\mathrm{t}, J=7.5 \mathrm{~Hz}, 1 \mathrm{H}), 7.30(\mathrm{t}, J=8.0 \mathrm{~Hz}, 1 \mathrm{H}), 4.45(\mathrm{~s}, 2 \mathrm{H}) .{ }^{13} \mathrm{C}$ NMR (DMSO- $\left.d_{6}\right): \delta$ $165.7,159.9,153.6,139.1,138.2,138.0,137.1,130.5,129.0,128.6,128.4,123.5,120.8,120.7$, 
112.4, 94.6, 59.2. HRMS (ESI, $m / z)$ : Calcd for $\mathrm{C}_{17} \mathrm{H}_{12} \mathrm{IN}_{2} \mathrm{O}_{2}\left([\mathrm{M}+\mathrm{H}]^{+}\right)$402.9944, found: 402.9930.

5-(3-Nitrophenyl)-1,3-dihydro-2H-benzofuro[3,2-e][1,4]diazepin-2-one (5e). Compound 5e was prepared with similar procedure as compound 5a from 4e. Yield: 84\%, pale yellow solid; mp 273 ${ }^{\circ} \mathrm{C}$ (dec.). ${ }^{1} \mathrm{H}$ NMR (DMSO-d $): \delta 11.68(\mathrm{~s}, 1 \mathrm{H}), 8.57$ (t, $\left.J=2.0 \mathrm{~Hz}, 1 \mathrm{H}\right), 8.41-8.39(\mathrm{~m}, 1 \mathrm{H})$, $8.22(\mathrm{dt}, J=1.0,8.0 \mathrm{~Hz}, 1 \mathrm{H}), 8.03(\mathrm{~d}, J=8.0 \mathrm{~Hz}, 1 \mathrm{H}), 7.81(\mathrm{t}, J=8.0 \mathrm{~Hz}, 1 \mathrm{H}), 7.70(J=8.5 \mathrm{~Hz}$, 1H), 7.62-7.58 (m, 1H), 7.46-7.43 (m, 1H), $4.52(\mathrm{~s}, 2 \mathrm{H})$.

5-(3-Methoxyphenyl)-1,3-dihydro-2H-benzofuro[3,2-e][1,4]diazepin-2-one (O-Me-5-BDBD, 5f). Compound $\mathbf{5 f}$ was prepared with similar procedure as compound 5a from 4f. Yield: 75\%, off white solid; mp 224-225 ${ }^{\circ} \mathrm{C} .{ }^{1} \mathrm{H}$ NMR (DMSO- $\left.d_{6}\right): \delta 11.53(\mathrm{~s}, 1 \mathrm{H}), 7.99(\mathrm{~d}, J=7.5 \mathrm{~Hz}, 1 \mathrm{H}), 7.69$ $(\mathrm{d}, J=8.5 \mathrm{~Hz}, 1 \mathrm{H}), 7.59-7.55(\mathrm{~m}, 1 \mathrm{H}), 7.44-7.28(\mathrm{~m}, 2 \mathrm{H}), 7.30-7.28(\mathrm{~m}, 2 \mathrm{H}), 7.13-7.11(\mathrm{~m}, 1 \mathrm{H})$, $4.44(\mathrm{~s}, 2 \mathrm{H}), 3.80(\mathrm{~s}, 3 \mathrm{H}) .{ }^{13} \mathrm{C}$ NMR (DMSO- $\left.d_{6}\right): \delta 165.9,161.0,159.1,153.5,138.8,137.4$, $129.4,128.6,128.4,123.4,121.4,120.8,120.8,116.4,113.8,112.3,59.1,55.2$. HRMS (ESI, $m / z)$ : Calcd for $\mathrm{C}_{18} \mathrm{H}_{15} \mathrm{~N}_{2} \mathrm{O}_{3}\left([\mathrm{M}+\mathrm{H}]^{+}\right)$307.1083, found: 307.1077 .

3.6. 5-(3-Hydroxyphenyl)-1,3-dihydro-2H-benzofuro[3,2-e][1,4]diazepin-2-one (6)

To a stirred suspension of compound $\mathbf{5 f}(1.1 \mathrm{~g}, 3.4 \mathrm{mmol})$ in anhydrous $\mathrm{CH}_{2} \mathrm{Cl}_{2}(30 \mathrm{~mL})$ was added $\mathrm{BBr}_{3}\left(1.0 \mathrm{M}\right.$ solution in $\left.\mathrm{CH}_{2} \mathrm{Cl}_{2}, 30 \mathrm{~mL}, 30.0 \mathrm{mmol}\right)$ dropwise at $-78{ }^{\circ} \mathrm{C}$ under $\mathrm{N}_{2}$ atmosphere. The reaction mixture was stirred overnight after warming up to RT slowly. The reaction was quenched with water in an ice-cooled bath, it was neutralized with aqueous $1 \mathrm{~N}$ $\mathrm{NaHCO}_{3}$ solution. The precipitate was collected by filtration and washed with water. The solid was dried in vacuo to afford 6 as a yellow solid (846 mg, 81\%); mp $234{ }^{\circ} \mathrm{C}$ (dec.). ${ }^{1} \mathrm{H}$ NMR 
(DMSO- $\left.d_{6}\right): \delta 11.50(\mathrm{~s}, 1 \mathrm{H}), 9.62(\mathrm{~s}, 1 \mathrm{H}), 7.98(\mathrm{~d}, J=8.0 \mathrm{~Hz}, 1 \mathrm{H}), 7.69(\mathrm{~d}, J=8.0 \mathrm{~Hz}, 1 \mathrm{H}), 7.57$ $(\mathrm{t}, J=7.5 \mathrm{~Hz}, 1 \mathrm{H}), 7.42(\mathrm{t}, J=7.5 \mathrm{~Hz}, 1 \mathrm{H}), 7.28(\mathrm{t}, J=8.0 \mathrm{~Hz}, 1 \mathrm{H}), 7.15(\mathrm{~s}, 2 \mathrm{H}), 6.93(\mathrm{~d}, J=7.5$ $\mathrm{Hz}, 1 \mathrm{H}), 4.41(\mathrm{~s}, 2 \mathrm{H}) .{ }^{13} \mathrm{C}$ NMR (DMSO- $\left.d_{6}\right): \delta 164.7,162.5,157.5,156.2,135.1,131.7,130.1$, 124.4, 122.4, 121.9, 120.8, 120.1, 117.5, 112.8, 54.0. LC-MS (ESI, $m / z)$ : Calcd for $\mathrm{C}_{17} \mathrm{H}_{13} \mathrm{~N}_{2} \mathrm{O}_{3}$ $\left([\mathrm{M}+\mathrm{H}]^{+}\right)$293.1, found: 293.0. HRMS (ESI, $\left.m / z\right)$ : Calcd for $\mathrm{C}_{18} \mathrm{H}_{15} \mathrm{~N}_{2} \mathrm{O}_{3}\left([\mathrm{M}+\mathrm{H}]^{+}\right)$293.0926, found: 293.0916.

3.7. tert-Butyl (3-(2-oxo-2,3-dihydro-1H-benzofuro[3,2-e][1,4]diazepin-5-yl)phenyl)carbonate (7)

A suspension of compound $6(50 \mathrm{mg}, 0.17 \mathrm{mmol}),(\mathrm{Boc})_{2} \mathrm{O}(250 \mathrm{mg}, 1.14 \mathrm{mmol})$ and DMAP (9 $\mathrm{mg}, 0.07 \mathrm{mmol})$ in $\mathrm{CH}_{3} \mathrm{CN}(2 \mathrm{~mL})$ was stirred at $\mathrm{RT}$ for $2.5 \mathrm{~h}$. The solvent was evaporated in vacuo. The crude product was purified by preparative TLC plate using $\mathrm{CH}_{2} \mathrm{Cl}_{2} / \mathrm{MeOH}$ (100:4) as eluent to afford 7 as a pale yellow solid (29 $\mathrm{mg}, 44 \%) ; \mathrm{mp} 182-183{ }^{\circ} \mathrm{C} .{ }^{1} \mathrm{H} \mathrm{NMR}\left(\mathrm{CDCl}_{3}\right): \delta 11.2$ (s, 1H), $7.92(\mathrm{~d}, J=7.5 \mathrm{~Hz}, 1 \mathrm{H}), 7.69-7.67(\mathrm{~m}, 2 \mathrm{H}), 7.53-7.52(\mathrm{~m}, 2 \mathrm{H}), 7.45(\mathrm{t}, J=8.0 \mathrm{~Hz}, 1 \mathrm{H})$,

7.42-7.38 (m, 1H), 7.33-7.30 (m, 1H), $4.63(\mathrm{~s}, 2 \mathrm{H}), 1.55$ (s, 9H). ${ }^{13} \mathrm{C}$ NMR (DMSO-d 6 ): $\delta$ 167.9, $161.8,154.2,151.8,151.2,139.6,137.6,129.4,128.8,128.4,126.8,124.1,123.8,122.2,121.0$ 120.2, 112.6, 83.9, 58.8, 27.8. HRMS (ESI, $m / z)$ : Calcd for $\mathrm{C}_{22} \mathrm{H}_{21} \mathrm{~N}_{2} \mathrm{O}_{5}\left([\mathrm{M}+\mathrm{H}]^{+}\right)$393.1450, found: 393.1434 .

3.8. General procedure for preparation of compound 8 
$B D B D, 8 c)$. To a stirred solution of compound 5c (200 $\mathrm{mg}, 0.56 \mathrm{mmol})$ in anhydrous DMF (2 $\mathrm{mL}$ ) was added $\mathrm{NaH}$ (60\% dispersion in mineral oil, $16 \mathrm{mg}, 0.67 \mathrm{mmol})$. The reaction mixture was stirred at RT for $15 \mathrm{~min}$, and methyl iodide ( $70 \mu \mathrm{L}, 1.12 \mathrm{mmol})$ was then added. After the mixture was stirred at RT for $30 \mathrm{~min}$, it was poured into ice-water and extracted with EtOAc. The organic layer was washed with water, brine, dried over anhydrous $\mathrm{Na}_{2} \mathrm{SO}_{4}$ and filtered. The solvent was evaporated in vacuo. The crude product was purified by preparative TLC plate using $\mathrm{CH}_{2} \mathrm{Cl}_{2} / \mathrm{MeOH}(100: 4)$ as eluent to afford $8 \mathrm{c}$ as a pale yellow solid (136 $\left.\mathrm{mg}, 65 \%\right)$; mp 158-160 ${ }^{\circ} \mathrm{C} .{ }^{1} \mathrm{H}$ NMR (DMSO- $\left.d_{6}\right): \delta 8.05(\mathrm{~d}, J=8.0 \mathrm{~Hz}, 1 \mathrm{H}), 7.94(\mathrm{~s}, 1 \mathrm{H}), 7.80-7.75(\mathrm{~m}, 3 \mathrm{H}), 7.60(\mathrm{t}, J=$ $8.0 \mathrm{~Hz}, 1 \mathrm{H}), 7.47(\mathrm{q}, J=8.0 \mathrm{~Hz}, 2 \mathrm{H}), 4.51(\mathrm{br} \mathrm{s}, 2 \mathrm{H}), 3.57(\mathrm{~s}, 3 \mathrm{H}) .{ }^{13} \mathrm{C} \mathrm{NMR}\left(\mathrm{CDCl}_{3}\right): \delta 164.8$, $159.9,153.4,139.6,137.7,133.5,131.9,131.2,130.6,128.3,128.0,123.9,121.8,121.7,121.5$, 112.8, 58.4, 33.9. HRMS (ESI, $m / z)$ : Calcd for $\mathrm{C}_{18} \mathrm{H}_{14} \mathrm{BrN}_{2} \mathrm{O}_{2}\left([\mathrm{M}+\mathrm{H}]^{+}\right)$369.0239, found: 369.0254.

5-(3-Methoxyphenyl)-1-methyl-1,3-dihydro-2H-benzofuro[3,2-e][1,4]diazepin-2-one $(8 f)$. Compound 8f was prepared with similar procedure as compound 8c from 5f. Yield: 90\%, pale yellow solid; mp 62-64 C. ${ }^{1} \mathrm{H}$ NMR $\left(\mathrm{CDCl}_{3}\right): \delta 7.81(\mathrm{~d}, J=8.5 \mathrm{~Hz}, 1 \mathrm{H}), 7.57(\mathrm{~d}, J=8.5 \mathrm{~Hz}$, $1 \mathrm{H}), 7.53(\mathrm{dt}, J=1.5,7.0 \mathrm{~Hz}, 1 \mathrm{H}), 7.43-7.35(\mathrm{~m}, 4 \mathrm{H}), 7.08-7.05(\mathrm{~m}, 1 \mathrm{H}), 4.57$ (br s, 2H), 3.86 (s, 3H), $3.64(\mathrm{~s}, 3 \mathrm{H}) .{ }^{13} \mathrm{C} \mathrm{NMR}\left(\mathrm{CDCl}_{3}\right): \delta 166.1,162.1,159.8,153.9,141.1,137.2,131.5,129.5$, 128.1, 123.9, 122.0, 121.9, 121.1, 117.4, 113.8, 113.1, 58.7, 55.6, 34.4. HRMS (ESI, $m / z)$ : Calcd for $\mathrm{C}_{19} \mathrm{H}_{17} \mathrm{~N}_{2} \mathrm{O}_{3}\left([\mathrm{M}+\mathrm{H}]^{+}\right)$321.1239, found: 321.1234 .

3.9. 5-(3-Hydroxyphenyl)-1-methyl-1,3-dihydro-2H-benzofuro[3,2-e][1,4]diazepin-2-one (N-Me5-BDBD analog, 9) 
To a stirred solution of compound $\mathbf{8 f}(60 \mathrm{mg}, 0.18 \mathrm{mmol})$ in anhydrous $\mathrm{CH}_{2} \mathrm{Cl}_{2}(1 \mathrm{~mL})$ was added $\mathrm{BBr}_{3}\left(1.0 \mathrm{M}\right.$ solution in $\left.\mathrm{CH}_{2} \mathrm{Cl}_{2}, 1.4 \mathrm{~mL}, 1.4 \mathrm{mmol}\right)$ dropwise at $-78{ }^{\circ} \mathrm{C}$ under $\mathrm{N}_{2}$ atmosphere. The reaction mixture was stirred overnight after warming up to RT slowly. The reaction was quenched with water in an ice-cooled bath, it was neutralized with aqueous $1 \mathrm{~N}$ $\mathrm{NaHCO}_{3}$ solution and extracted with $\mathrm{CH}_{2} \mathrm{Cl}_{2}$. The solvent was evaporated in vacuo. The crude product was purified by preparative TLC plate using $\mathrm{CH}_{2} \mathrm{Cl}_{2} / \mathrm{MeOH}(100: 4)$ as eluent to afford 9 as a pale yellow solid (41 mg, 72\%); mp 227-228 ${ }^{\circ} \mathrm{C} .{ }^{1} \mathrm{H}$ NMR (DMSO- $\left.d_{6}\right): \delta 9.65(\mathrm{~s}, 1 \mathrm{H}), 8.04$ $(\mathrm{d}, J=8.0 \mathrm{~Hz}, 1 \mathrm{H}), 7.75(\mathrm{~d}, J=8.0 \mathrm{~Hz}, 1 \mathrm{H}), 7.61-7.58(\mathrm{~m}, 1 \mathrm{H}), 7.46(\mathrm{t}, J=7.5 \mathrm{~Hz}, 1 \mathrm{H}), 7.29(\mathrm{t}$, $J=8.0 \mathrm{~Hz}, 1 \mathrm{H}), 7.20-7.19(\mathrm{~m}, 2 \mathrm{H}), 6.95-6.93(\mathrm{~m}, 1 \mathrm{H}), 4.46(\mathrm{br} \mathrm{s}, 2 \mathrm{H}), 3.56(\mathrm{~s}, 3 \mathrm{H}) .{ }^{13} \mathrm{C} \mathrm{NMR}$ (DMSO- $\left.d_{6}\right): \delta 165.3,161.1,157.3,153.2,140.4,136.8,131.3,129.4,128.1,123.8,121.7,121.5$ 119.8, 117.9, 115.4, 112.7, 58.2, 33.8. LC-MS (ESI, $m / z)$ : Calcd for $\mathrm{C}_{18} \mathrm{H}_{15} \mathrm{~N}_{2} \mathrm{O}_{3}\left([\mathrm{M}+\mathrm{H}]^{+}\right)$ 307.1, found: 307.1. HRMS (ESI, $m / z)$ : Calcd for $\mathrm{C}_{18} \mathrm{H}_{15} \mathrm{~N}_{2} \mathrm{O}_{3}\left([\mathrm{M}+\mathrm{H}]^{+}\right)$307.1083, found: 307.1070.

3.10. 2-(3-(2-Oxo-2,3-dihydro-1H-benzofuro[3,2-e][1,4]diazepin-5-yl)phenoxy)ethyl 4methylbenzenesulfonate (10)

To a stirred solution of compound 6 (200 mg, $0.7 \mathrm{mmol})$ in anhydrous DMF (4 mL) was added $\mathrm{NaH}(60 \%$ dispersion in mineral oil, $82 \mathrm{mg}, 2.0 \mathrm{mmol})$ at $0{ }^{\circ} \mathrm{C}$ under $\mathrm{N}_{2}$ atmosphere and the mixture was stirred at $0{ }^{\circ} \mathrm{C}$ for $45 \mathrm{~min}$, followed by addition of 1,2-bis(tosyloxy)ethane (504 $\mathrm{mg}$, $1.4 \mathrm{mmol})$. After the reaction mixture was stirred at $0{ }^{\circ} \mathrm{C}$ for $6 \mathrm{~h}$, it was poured into ice-water and extracted with EtOAc. The organic layer was washed with water, brine, dried over anhydrous 
$\mathrm{Na}_{2} \mathrm{SO}_{4}$ and filtered. The solvent was evaporated in vacuo. The crude product was purified by preparative TLC plate using $\mathrm{CH}_{2} \mathrm{Cl}_{2} / \mathrm{MeOH}$ (100:4) as eluent to afford $\mathbf{1 0}$ as a yellow solid (144 $\mathrm{mg}, 43 \%$ ); mp $188-189{ }^{\circ} \mathrm{C} .{ }^{1} \mathrm{H}$ NMR (DMSO- $\left.d_{6}\right): \delta 11.55$ (s, $\left.1 \mathrm{H}\right), 8.00(\mathrm{~d}, J=8.0 \mathrm{~Hz}, 1 \mathrm{H}), 7.79$ $(\mathrm{d}, J=8.5 \mathrm{~Hz}, 2 \mathrm{H}), 7.69(\mathrm{~d}, J=8.5 \mathrm{~Hz}, 1 \mathrm{H}), 7.60-7.56(\mathrm{~m}, 1 \mathrm{H}), 7.44-7.36(\mathrm{~m}, 4 \mathrm{H}), 7.30(\mathrm{~d}, J=$ $7.5 \mathrm{~Hz}, 1 \mathrm{H}), 7.13(\mathrm{t}, J=2.0 \mathrm{~Hz}, 1 \mathrm{H}), 7.03-7.01(\mathrm{~m}, 1 \mathrm{H}), 4.44(\mathrm{~s}, 2 \mathrm{H}), 4.37-4.35(\mathrm{~m}, 2 \mathrm{H}), 4.21-$ $4.19(\mathrm{~m}, 2 \mathrm{H}), 2.36(\mathrm{~s}, 3 \mathrm{H}) .{ }^{13} \mathrm{C}$ NMR (DMSO- $\left.d_{6}\right): \delta 165.9,160.9,157.6,153.5,144.9,138.7$, $137.4,132.3,130.1,129.5,128.7,128.5,127.7,123.5,121.9,120.8,116.8,114.6,112.4,69.1$, 65.4, 59.1, 21.0. LC-MS (ESI, $m / z$ ): Calcd for $\mathrm{C}_{26} \mathrm{H}_{23} \mathrm{~N}_{2} \mathrm{O}_{6} \mathrm{~S}$ ([M+H] $]^{+}$) 491.1, found: 491.1. HRMS (ESI, $m / z$ ): Calcd for $\mathrm{C}_{26} \mathrm{H}_{23} \mathrm{~N}_{2} \mathrm{O}_{6} \mathrm{~S}\left([\mathrm{M}+\mathrm{H}]^{+}\right)$491.1277, found: 491.1265 .

3.11. 5-(3-(2-Fluoroethoxy)phenyl)-1,3-dihydro-2H-benzofuro[3,2-e][1,4]diazepin-2-one (FE-5$B D B D, 11)$

To a stirred solution of compound $\mathbf{6}(100 \mathrm{mg}, 0.3 \mathrm{mmol})$ in anhydrous DMF $(2 \mathrm{~mL})$ was added $\mathrm{NaH}(60 \%$ dispersion in mineral oil, $41 \mathrm{mg}, 1.0 \mathrm{mmol})$ at $0{ }^{\circ} \mathrm{C}$ under $\mathrm{N}_{2}$ atmosphere and the mixture was stirred $0{ }^{\circ} \mathrm{C}$ for $45 \mathrm{~min}$, followed by addition of a solution of 2-fluoroethyl tosylate (111 mg, $0.5 \mathrm{mmol})$ in anhydrous DMF $(1 \mathrm{~mL})$. After the reaction mixture was stirred at $0{ }^{\circ} \mathrm{C}$ for $6 \mathrm{~h}$, it was poured into ice-water and extracted with EtOAc. The organic layer was washed with water, brine, dried over anhydrous $\mathrm{Na}_{2} \mathrm{SO}_{4}$ and filtered. The solvent was evaporated in vacuo. The crude product was purified by preparative TLC plate using $\mathrm{CH}_{2} \mathrm{Cl}_{2} / \mathrm{MeOH}$ (100:4) as eluent to afford 11 as a yellow solid $(75 \mathrm{mg}, 65 \%)$; mp 215-216 ${ }^{\circ} \mathrm{C} .{ }^{1} \mathrm{H}$ NMR (DMSO- $d_{6}$ ): $\delta 11.55$ (s, $1 \mathrm{H}), 8.00(\mathrm{~d}, J=8.0 \mathrm{~Hz}, 1 \mathrm{H}), 7.70(\mathrm{~d}, J=8.5 \mathrm{~Hz}, 1 \mathrm{H}), 7.59-7.56(\mathrm{~m}, 1 \mathrm{H}), 7.44-7.41(\mathrm{~m}, 2 \mathrm{H})$, 7.34-7.32 (m, 2H), 7.17-7.15 (m, 1H), $4.80(\mathrm{t}, J=4.0 \mathrm{~Hz}, 1 \mathrm{H}), 4.71(\mathrm{t}, J=4.0 \mathrm{~Hz}, 1 \mathrm{H}), 4.44(\mathrm{~s}$, 
$2 \mathrm{H}), 4.32(\mathrm{t}, J=4.0 \mathrm{~Hz}, 1 \mathrm{H}), 4.26(\mathrm{t}, J=4.0 \mathrm{~Hz}, 1 \mathrm{H}) .{ }^{13} \mathrm{C}$ NMR (DMSO- $\left.d_{6}\right): \delta 165.9,161.0$, $158.1,153.5,138.7,137.4,129.6,128.7,128.5,123.5,121.9,120.8,120.8,117.1,114.5,112.4$, $82.7(\mathrm{~d}, J=165 \mathrm{~Hz}), 67.2$, 59.1. LC-MS (ESI, $m / z)$ : Calcd for $\mathrm{C}_{19} \mathrm{H}_{16} \mathrm{FN}_{2} \mathrm{O}_{3}\left([\mathrm{M}+\mathrm{H}]^{+}\right)$339.1, found: 339.0. HRMS (ESI, $m / z$ ): Calcd for $\mathrm{C}_{19} \mathrm{H}_{16} \mathrm{FN}_{2} \mathrm{O}_{3}\left([\mathrm{M}+\mathrm{H}]^{+}\right)$339.1145, found: 339.1140 .

\subsection{General procedure for preparation of carbon-11-labeled 5-BDBD analogs}

5-(3-Hydroxyphenyl)-1- $\left[{ }^{11}\right.$ C]methyl-1,3-dihydro-2H-benzofuro[3,2-e][1,4]diazepin-2-one $\quad(\mathrm{N}$ $\left[{ }^{11} \mathrm{C}\right] \mathrm{Me-5-BDBD}$ analog, $\left.\left[{ }^{11} \mathrm{C}\right] 9\right)$ and 5-(3-bromophenyl)-1- $\left[{ }^{11} \mathrm{C}\right]$ methyl-1,3-dihydro-2Hbenzofuro[3,2-e][1,4]diazepin-2-one $\left.\left(N-{ }^{11} C\right] M e-5-B D B D,\left[{ }^{11} C\right] 8 c\right) .\left[{ }^{11} \mathrm{C}_{C} \mathrm{CO}_{2}\right.$ was produced by the ${ }^{14} \mathrm{~N}(\mathrm{p}, \alpha){ }^{11} \mathrm{C}$ nuclear reaction in the small volume $\left(9.5 \mathrm{~cm}^{3}\right)$ aluminum gas target provided with the Siemens RDS-111 Eclipse cyclotron. The target gas consisted of 1\% oxygen in nitrogen purchased as a specialty gas from Praxair, Indianapolis, IN. Typical irradiations used for the development were $58 \mu \mathrm{A}$ beam current and $15 \mathrm{~min}$ on target. The production run produced approximately $25.9 \mathrm{GBq}$ of $\left[{ }^{11} \mathrm{C}\right] \mathrm{CO}_{2}$ at EOB. The precursor $(\mathbf{6}$ or $\mathbf{5 c}, 0.1-0.3 \mathrm{mg})$ was dissolved in $\mathrm{CH}_{3} \mathrm{CN}(300 \mu \mathrm{L})$. To this solution was added $\mathrm{NaH}(95 \%$ dispersion in mineral oil, $1 \mathrm{mg})$. The mixture was transferred to a small reaction vial. No-carrier-added (high specific activity) $\left[{ }^{11} \mathrm{C}_{\mathrm{CH}_{3}} \mathrm{OTf}\right.$ that was produced by the gas-phase production method ${ }^{20}$ within 12 min from $\left[{ }^{11} \mathrm{C}_{\mathrm{CO}_{2}}\right.$ through $\left[{ }^{11} \mathrm{C}\right] \mathrm{CH}_{4}$ and $\left[{ }^{11} \mathrm{C}\right] \mathrm{CH}_{3} \mathrm{Br}$ with silver triflate (AgOTf) column was passed into the reaction vial at RT until radioactivity reached a maximum (2 min), and then the reaction vial was isolated and heated at $80{ }^{\circ} \mathrm{C}$ for $3 \mathrm{~min}$. The contents of the reaction vial were diluted with aqueous $\mathrm{NaHCO}_{3}(0.1 \mathrm{M}, 1 \mathrm{~mL})$. The reaction vial was connected to a 3-mL HPLC injection loop. The labeled product mixture solution was injected onto the semi-preparative HPLC column 
for purification. The product fraction was collected in a recovery vial containing $30 \mathrm{~mL}$ water. The diluted tracer solution was then passed through a C-18 Sep-Pak Light cartridge, and washed with water $(3 \times 10 \mathrm{~mL})$. The cartridge was eluted with $\mathrm{EtOH}(3 \times 0.4 \mathrm{~mL})$ to release the labeled product, followed by saline $(10-11 \mathrm{~mL})$. The eluted product was then sterile-filtered through a Millex-FG $0.2 \mu \mathrm{m}$ membrane into a sterile vial. Total radioactivity of $\left[{ }^{11} \mathrm{C}\right] \mathbf{9}$ or $\left[{ }^{11} \mathrm{C}\right] \mathbf{8 c}$ was assayed and total volume (10-11 mL) was noted for tracer dose dispensing. The overall synthesis time including HPLC-SPE purification and reformulation was $\sim 40 \mathrm{~min}$ from EOB. The decay corrected radiochemical yield for $\left[{ }^{11} \mathrm{C}\right] \mathbf{9}$ and $\left[{ }^{11} \mathrm{C}\right] \mathbf{8 c}$ was $30-50 \%$. Retention times in the analytical HPLC system performed using a Prodigy (Phenomenex) $5 \mu \mathrm{m} \mathrm{C-18} \mathrm{column,} 4.6 \times 250$ $\mathrm{mm}$; mobile phase $30 \% \mathrm{CH}_{3} \mathrm{CN} / 70 \% 20 \mathrm{mM} \mathrm{H}_{3} \mathrm{PO}_{4}$; flow rate $1.0 \mathrm{~mL} / \mathrm{min}$; and $\mathrm{UV}$ (254 nm) and $\gamma$-ray (PIN diode) flow detectors were: $\mathrm{t}_{\mathrm{R}} \mathbf{6}=3.68 \mathrm{~min}, \mathrm{t}_{\mathrm{R}} \mathbf{9}=6.61 \mathrm{~min}, \mathrm{t}_{\mathrm{R}}\left[{ }^{11} \mathrm{C}\right] \mathbf{9}=6.66 \mathrm{~min}$. Retention times in the semi-preparative HPLC system performed using a Prodigy (Phenomenex) $5 \mu \mathrm{m} \mathrm{C}$ - 18 column, $10 \times 250 \mathrm{~mm}$; mobile phase $30 \% \mathrm{CH}_{3} \mathrm{CN} / 70 \% 20 \mathrm{mM} \mathrm{H}_{3} \mathrm{PO}_{4}$; flow rate 5.0 $\mathrm{mL} / \mathrm{min}$; and UV (254 nm) and $\gamma$-ray (PIN diode) flow detectors were: $\mathrm{t}_{\mathrm{R}} \mathbf{6}=4.88 \mathrm{~min}, \mathrm{t}_{\mathrm{R}} \mathbf{9}=$ $7.65 \mathrm{~min}, \mathrm{t}_{\mathrm{R}}\left[{ }^{11} \mathrm{C}\right] 9=7.77 \mathrm{~min}$. Retention times in the analytical HPLC system performed using a Prodigy (Phenomenex) $5 \mu \mathrm{m}$ C-18 column, $4.6 \times 250 \mathrm{~mm}$; mobile phase $70 \% \mathrm{CH}_{3} \mathrm{CN} / 30 \% \mathrm{H}_{2} \mathrm{O}$; flow rate $1.3 \mathrm{~mL} / \mathrm{min}$; and $\mathrm{UV}(254 \mathrm{~nm})$ and $\gamma$-ray (PIN diode) flow detectors were: $\mathrm{t}_{\mathrm{R}} \mathbf{5 c}=4.11$ $\min , t_{R} 8 \mathbf{c}=6.12 \mathrm{~min}, t_{R}\left[{ }^{11} \mathrm{C}\right] \mathbf{8 c}=6.19$ min. Retention times in the semi-preparative HPLC system performed using a Prodigy (Phenomenex) $5 \mu \mathrm{m} \mathrm{C}-18$ column, $10 \times 250 \mathrm{~mm}$; mobile phase $70 \% \mathrm{CH}_{3} \mathrm{CN} / 30 \% \mathrm{H}_{2} \mathrm{O}$; flow rate $5.0 \mathrm{~mL} / \mathrm{min}$; and $\mathrm{UV}(254 \mathrm{~nm})$ and $\gamma$-ray (PIN diode) flow detectors were: $\mathrm{t}_{\mathrm{R}} \mathbf{5 c}=3.56 \mathrm{~min}, \mathrm{t}_{\mathrm{R}} \mathbf{8 c}=7.91 \mathrm{~min}, \mathrm{t}_{\mathrm{R}}\left[{ }^{11} \mathrm{C}\right] \mathbf{8 c}=8.00 \mathrm{~min}$.

\subsection{General procedure for preparation of fluorine-18-labeled 5-BDBD analogs}


5-(3- $\left[{ }^{18}\right.$ F]Fluorophenyl)-1,3-dihydro-2H-benzofuro[3,2-e][1,4]diazepin-2-one $\left(\left[{ }^{18} \mathrm{~F}\right] \mathrm{F}-5-\mathrm{BDBD}\right.$, $\left.\left[{ }^{18} \mathrm{~F}\right] 5 \boldsymbol{5 a}\right)$ and 5-(3-(2- $\left[{ }^{18} \mathrm{~F}\right]$ fluoroethoxy)phenyl)-1,3-dihydro-2H-benzofuro[3,2-e][1,4]diazepin2-one $\left(\left[{ }^{18} F\right] F E-5-B D B D,\left[{ }^{18} F\right] 11\right)$. No-carrier-added (NCA) aqueous $\mathrm{H}\left[{ }^{18} \mathrm{~F}\right] \mathrm{F}$ was produced by ${ }^{18} \mathrm{O}(\mathrm{p}, \mathrm{n}){ }^{18} \mathrm{~F}$ nuclear reaction using a Siemens Eclipse RDS- 111 cyclotron by irradiation of $\mathrm{H}_{2}{ }^{18} \mathrm{O}$ (2.5 mL). $\left[{ }^{18} \mathrm{~F}\right]$ Fluoride $(7.4-18.5 \mathrm{GBq})$ in $\left[{ }^{18} \mathrm{O}\right]$ water plus $0.1 \mathrm{~mL} \mathrm{~K}_{2} \mathrm{CO}_{3}$ solution $(1.7 \mathrm{mg})$ and Kryptofix 2.2.2 $(10 \mathrm{mg})$ in $1.0 \mathrm{~mL} \mathrm{CH}_{3} \mathrm{CN}$ were placed in the fluorination reaction vial $(5-\mathrm{mL}$ $\mathrm{V}$-vial) and repeated azeotropic distillation was performed at $110^{\circ} \mathrm{C}$ to remove water and to form the anhydrous $\mathrm{K}\left[{ }^{18} \mathrm{~F}\right] \mathrm{F}-$ Kryptofix 2.2.2 complex. Nitro- precursor $5 \mathbf{e}$ or tosylated precursor $10(1 \mathrm{mg})$ dissolved in DMSO $(1.0 \mathrm{~mL})$ was introduced to the reaction vessel and heated at 140 ${ }^{\circ} \mathrm{C}$ for 20 min to affect radiofluorination. After cooling to $\sim 90{ }^{\circ} \mathrm{C}$, aqueous $\mathrm{NaHCO}_{3}(0.1 \mathrm{M}, 1$ $\mathrm{mL}$ ) was added to the reaction vessel for dilution, at which time the reaction mixture was loaded into a 3-mL injection loop for introduction to the semi-preparative reverse-phase (C18) HPLC column for initial purification of the labeled product. The HPLC fraction containing $\left[{ }^{18} \mathrm{~F}\right] \mathbf{5 a}$ or $\left[{ }^{18} \mathrm{~F}\right] \mathbf{1 1}$ eluted from the column was automatically collected in a recovery vial containing $30 \mathrm{~mL}$ water. The diluted tracer solution was then passed through a C-18 Sep-Pak Plus cartridge, and washed with water $(5 \times 5 \mathrm{~mL})$. The cartridge was eluted with $\mathrm{EtOH}(2 \times 1 \mathrm{~mL})$ to release $\left[{ }^{18} \mathrm{~F}\right] \mathbf{5 a}$ or $\left[{ }^{18} \mathrm{~F}\right] \mathbf{1 1}$. The eluted product was then sterile-filtered through a Millex-FG $0.2 \mu \mathrm{m}$ membrane into a sterile vial and formulated with $10 \mathrm{~mL}$ saline. Total radioactivity was assayed and total volume was noted for tracer dose dispensing. The overall decay-corrected radiochemical yield from $\mathrm{K}\left[{ }^{18} \mathrm{~F}\right] \mathrm{F}$ for $\left[{ }^{18} \mathrm{~F}\right] \mathbf{5 a}$ and $\left[{ }^{18} \mathrm{~F}\right] \mathbf{1 1}$ was $5-15 \%$ and $15-25 \%$, respectively. Retention times in the semi-preparative HPLC system performed using a YMC-Pack ODS-A (Phenomenex), S-5 $\mu \mathrm{m}, 12 \mathrm{~nm}, 10 \times 250 \mathrm{~mm}$ C-18 column; 30\% $\mathrm{CH}_{3} \mathrm{CN} / 70 \% 20 \mathrm{mM} \mathrm{H}_{3} \mathrm{PO}_{4}(\mathrm{pH} 2.5)$ mobile phase; 
$5.0 \mathrm{~mL} / \mathrm{min}$ flow rate; $\mathrm{UV}(254 \mathrm{~nm})$ and $\gamma$-ray (PIN diode) flow detectors were: $\mathrm{t}_{\mathrm{R}} \mathbf{5 e}=9.65 \mathrm{~min}$, $\mathrm{t}_{\mathrm{R}} \mathbf{5 a}=12.64 \mathrm{~min}, \mathrm{t}_{\mathrm{R}}\left[{ }^{18} \mathrm{~F}\right] \mathbf{5 a}=12.71 \mathrm{~min} ; \mathrm{t}_{\mathrm{R}} \mathbf{1 0}=19.13 \mathrm{~min}, \mathrm{t}_{\mathrm{R}} \mathbf{1 1}=8.87 \mathrm{~min}, \mathrm{t}_{\mathrm{R}}\left[{ }^{18} \mathrm{~F}\right] \mathbf{1 1}=8.95$ min. Retention times in the analytical HPLC system performed using a Prodigy (Phenomenex) 5 $\mu \mathrm{m}$ C-18 column, $4.6 \times 250 \mathrm{~mm}$; mobile phase $30 \% \mathrm{CH}_{3} \mathrm{CN} / 70 \% 20 \mathrm{mM} \mathrm{H}_{3} \mathrm{PO}_{4}$; flow rate 1.3 $\mathrm{mL} / \mathrm{min}$; and UV (254 nm) and $\gamma$-ray (PIN diode) flow detectors were: $\mathrm{t}_{\mathrm{R}} \mathbf{5 e}=6.59 \mathrm{~min}, \mathrm{t}_{\mathrm{R}} \mathbf{5} \mathbf{a}=$ $9.94 \mathrm{~min}, \mathrm{t}_{\mathrm{R}}\left[{ }^{18} \mathrm{~F}\right] \mathbf{5 a}=10.02 \mathrm{~min} ; \mathrm{t}_{\mathrm{R}} \mathbf{1 0}=10.55 \mathrm{~min}, \mathrm{t}_{\mathrm{R}} \mathbf{1 1}=6.89 \mathrm{~min}, \mathrm{t}_{\mathrm{R}}\left[{ }^{18} \mathrm{~F}\right] \mathbf{1 1}=7.03 \mathrm{~min}$.

\subsection{In vitro binding studies}

Cell culture and membrane preparation. HEK293 cells expressing human recombinant P2X4 receptors were obtained from B'SYS GmbH and cultured according to supplier's procedure. Cells were grown to $80 \%$ confluency then rinsed with phosphate buffered saline (PBS), detached with trypsin and harvested. Cell pellets were obtained by centrifugation at 200xG for 5 min at 4 ${ }^{\circ} \mathrm{C}$. Collected cell pellets were frozen at $-80^{\circ} \mathrm{C}$ until membrane preparation. For the membrane preparation, pellets from ten T225 flasks were homogenized in $50 \mathrm{mM}$ Tris-HCl, $1 \mathrm{mM}$ EDTA pH 7.4 plus $0.1 \%$ bacitracin, $100 \mu \mathrm{M}$ PMSF at $4{ }^{\circ} \mathrm{C}$. The homogenate was then centrifuged at $48000 \times \mathrm{G}$ for 20 min at $4{ }^{\circ} \mathrm{C}$, gently rinsed with de-ionized water then resuspended in $5 \mathrm{~mL}$ of buffer $\mathrm{pH} 7.4$ at $4{ }^{\circ} \mathrm{C}$. This homogenate was then frozen at $-80{ }^{\circ} \mathrm{C}$, then thawed, an additional 30 $\mathrm{mL}$ buffer added and centrifuged as before. The freeze/thaw procedure repeated once. The final resulting pellet was homogenized in buffer, total protein concentration determined via Bradford protein assay (Bio-Rad), aliquoted into cryovials and stored at $-80^{\circ} \mathrm{C}$ until day of assay.

Radioligand depletion experiments. Radioligand depletion experiments were performed to measure the bound radioligand concentration. Four replicates of membrane preparation (0.004- 
$4.5 \mathrm{mg}$ protein/mL assay medium) were incubated with $10 \mathrm{nM}$ or $100 \mathrm{nM}\left[{ }^{11} \mathrm{C}\right] \mathbf{9}$ or $\left[{ }^{11} \mathrm{C}\right] \mathbf{8 c}$ in a final volume of $0.2 \mathrm{~mL}$ in assay buffer $(50 \mathrm{mM}$ Tris- $\mathrm{HCl}, 1 \mathrm{mM}$ EDTA $\mathrm{pH} 7.4$ plus $0.1 \%$ bacitracin, $100 \mu \mathrm{M}$ PMSF) for $30 \mathrm{~min}$ at $37^{\circ} \mathrm{C}$. Unlabeled compound $\mathbf{9}$ or $8 \mathbf{c}$ was added at 100 fold excess of $\left[{ }^{11} \mathrm{C}\right] \mathbf{9}$ or $\left[{ }^{11} \mathrm{C}\right] \mathbf{8 c}$ to determine non-specific binding. To measure the total radioactivity added to the experiment, $20 \mu \mathrm{L}$ of stock radioligand (amount added to each experimental well) was spotted onto a unifilter GF/B plate then allowed to air dry. An additional aliquot was added to scintillation vial and counted on a Beckman LSC to determine CPMs (counts per minute) added. For termination of the binding reaction, the samples were filtered onto GF/B unifilter plates that had been pre-soaked in $20 \mathrm{mM}$ tetrasodium pyrophosphate for 30 min using a unifilter-96 cell harvester (Perkin-Elmer). Plates were washed 6 times with ice cold saline, dried under a vacuum, and exposed to a TR2025 phosphorscreen (GE Healthcare) for 20 to 60 min. Phosphorscreens were then read on Typhoon FLA-7000IP (GE Healthcare) along with $\left[{ }^{11} \mathrm{C}\right] \mathbf{9}$ or $\left[{ }^{11} \mathrm{C}\right] \mathbf{8 c}$ calibration standards. CPMs were determined by calibrating the image to the CPMs in the calibration standards via MCID analysis Software.

Ligand competitive binding assays. Cell membrane preparation (5 $\mu \mathrm{g}$ per well) was incubated with 11 compound concentrations over a six log unit range, with $0.2 \mathrm{nM}\left[{ }^{35} \mathrm{~S}\right] \mathrm{ATP} \gamma \mathrm{S}$ (Perkin Elmer) in assay buffer. Triplicate determinations were done at each concentration of test compound 5-BDBD (5c), $N$-Me-5-BDBD (8c), $N$-Me-5-BDBD analog (9), F-5-BDBD (5a) or FE-5-BDBD (11). Unlabeled ATP was used to determine non-specific binding. Each assay plate included a positive control (ATP) and a negative control (buffer). Assays were incubated at $4{ }^{\circ} \mathrm{C}$ for $2 \mathrm{~h}$. After equilibrium was reached, bound radioligand was separated from free radioligand using a Perkin Elmer 96-well filtration apparatus. Plates were washed at least 3 times with ice cold saline. Filters were quickly dried under a vacuum and radioactive counts collected on a 
Perkin Elmer TopCount microplate scintillation counter using a protocol for ${ }^{35} \mathrm{~S}$. Data was analyzed with Prism 7 (GraphPad Software Inc.) to determine $K i$ values.

\section{Conclusions}

In summary, improved and efficient syntheses of a series of new 5-BDBD analog precursors (for C-11 and F-18 labeling) and reference standards with moderate to high chemical yields have been developed. The amide precursors were labeled with $\left[{ }^{11} \mathrm{C}\right] \mathrm{CH}_{3} \mathrm{OTf}$ via $N-\left[{ }^{11} \mathrm{C}\right]$ methylation, and isolated by a semi-preparative HPLC purification combined with SPE procedure to provide carbon-11-labeled 5-BDBD analogs in high radiochemical yields, short overall synthesis time, and good specific radioactivity. The nitro- and tosylated precursors were labeled with $\mathrm{K}\left[{ }^{18} \mathrm{~F}\right] \mathrm{F} /$ Kryptofix 2.2 .2 through nucleophilic substitution and isolated by a semi-preparative HPLC combined with SPE method to produce fluorine-18-labeled 5-BDBD analogs in reasonable radiochemical yield and good specific radioactivity. The preliminary biological evaluation of radiolabeled 5-BDBD analogs indicated they have similar biological activity with the parent compound 5-BDBD. It is anticipated that the approaches described here can be applied with advantage to the development of more potent PET P2X4 radioligands, and other receptor- and/or enzyme-based ${ }^{11} \mathrm{C}$ - and ${ }^{18}$ F-radioligands for PET imaging.

\section{Acknowledgments}


This work was partially supported by the Biomedical Research Grant from the Indiana University School of Medicine and the Advanced Imaging Research and Technology Development (AIRTD) grants from the Department of Radiology and Imaging Sciences at Indiana University School of Medicine in the United States. ${ }^{1} \mathrm{H}$ NMR and ${ }^{13} \mathrm{C}$ NMR spectra were recorded at 500 and $125 \mathrm{MHz}$, respectively, on a Bruker Avance II $500 \mathrm{MHz}$ NMR spectrometer in the Department of Chemistry and Chemical Biology at Indiana University Purdue University Indianapolis (IUPUI), which is supported by the United States National Science Foundation (NSF) Major Research Instrumentation Program (MRI) grant CHE-0619254.

\section{References}

1. Coddou C, Yan Z, Obsil T, Huidobro-Toro JP, Stojilkovic SS. Pharmacol Rev. 2011;63:641-683.

2. Burnstock G. Keio J Med. 2013;62:63-73.

3. Idzko M, Ferrari D, Eltzschig HK. Nature. 2014;509(7500):310-317.

4. Woods LT, Ajit D, Camden JM, Erb L, Weisman GA. Neuropharmacology. 2016;104:169179.

5. Gao M, Wang M, Green MA, Hutchins GD, Zheng Q-H. Bioorg Med Chem Lett. $2015 ; 25: 1965-1970$.

6. Territo PR, Meyer JA, Peters JS, et al. J Nucl Med. 2017;58:458-465.

7. Balázs B, Dankó T, Kovács G, Köles L, Hediger MA, Zsembery A. Cell Physiol Biochem. 2013;32:11-24. 
8. Lee H, Finck BN, Jones LA, Welch MJ, Mach RH. Nucl Med Biol. 2006;33:847-854.

9. Rowland DJ, Tu Z, Xu J, Ponde D, Mach RH, Welch MJ. J Nucl Med. 2006;47:1041-1048.

10. Kamal M, Shakya AK, Ahsan MJ, Jawaid T. Cent Nerv Syst Agents Med Chem. 2013;13:159-165.

11. King LC, Ostrum GK. J Org Chem. 1964;29:3459-3461.

12. Boominathan SSK, Hu WP, Senadi GC, Wang JJ. Adv Synth Catal. 2013;355:3570-3574.

13. Fischer R, Kalthof B, Stelte-ludwig B, Woltering E, Wuttke M. CA 2519987 A1 2004.

14. Wang M, Gao M, Miller KD, Sledge GW, Hutchins GD, Zheng Q-H. J Label Comp.Radiopharm. 2008;51:6-11.

15. Wang J-Q, Gao M, Miller KD, Sledge GW, Zheng Q-H. Bioorg Med Chem Lett. 2006;16:4102-4106.

16. Wang M, Gao M, Zheng Q-H. Appl Radiat Isot. 2012;70:965-973.

17. Wang M, Gao M, Xu Z, Zheng Q-H. Bioorg Med Chem Lett. 2015;25:4587-4592.

18. Wang M, Gao M, Xu Z, Zheng Q-H. Bioorg Med Chem Lett. 2017;27:1351-1355.

19. Jewett DM. Int J Rad Appl Instrum A. 1992;43:1383-1385.

20. Mock BH, Mulholland GK, Vavrek MT. Nucl Med Biol. 1999;26:467-471.

21. Wang M, Gao M, Miller KD, Zheng Q-H. Steroids. 2011;76:1331-1340.

22. Wang M, Gao M, Miller KD, Sledge GW, Zheng Q-H. Bioorg Med Chem Lett. 2012;22:1569-1574.

23. Wang M, Gao M, Zheng Q-H. Bioorg Med Chem Lett. 2014;24:4455-4459.

24. Wang M, Gao M, Zheng Q-H. Bioorg Med Chem Lett. 2013;23:5259-5263.

25. Mock BH, Zheng Q-H, DeGrado TR. J Label Compd Radiopharm. 2005;48:S225. 
26. Mock BH, Glick-Wilson BE, Zheng Q-H, DeGrado TR. J Label Compd Radiopharm. 2005;48:S224.

27. Zheng Q-H, Mock BH. Biomed Chromatogr. 2005;19:671-676.

28. Gao M, Wang M, Zheng Q-H. Bioorg Med Chem Lett. 2015;25:2953-2957.

29. Gao M, Wang M, Mock BH, et al. Appl Radiat Isot. 2010;68:1079-1086.

30. Kuhnast B, Hinnen F, Dolle F. J Label Compd Radiopharm. 2009;52:S286.

31. Gao M, Wang M, Meyer JA, et al. Bioorg Med Chem Lett. 2017;27: DOI 10.1016/j.bmcl.2017.04.052.

32. Abdelrahman A, Namasivayam V, Hinz S, et al. Biochem Pharmacol. 2017;125:41-54. 


\section{Graphical Abstract}

Synthesis and preliminary biological evaluation of radiolabeled 5-BDBD analogs as new candidate PET radioligands for P2X4 receptor

Min Wang, Mingzhang Gao, Jill A. Meyer, Jonathan S. Peters, Hamideh Zarrinmayeh, Paul R. Territo, Gary D. Hutchins, Qi-Huang Zheng*
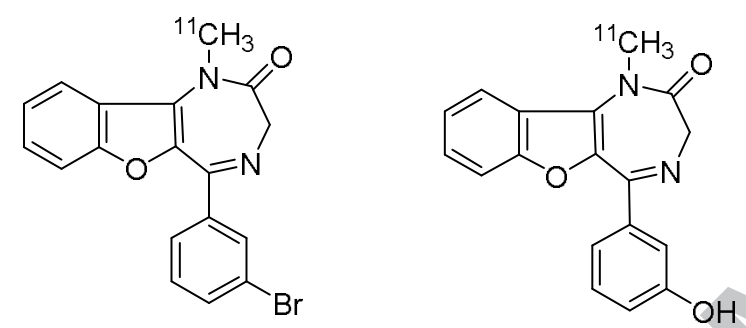

$N-\left[{ }^{11} \mathrm{C}\right] \mathrm{Me}-5-B D B D\left(\left[{ }^{11} \mathrm{C}\right] \mathbf{8 c}\right) \quad N-\left[{ }^{11} \mathrm{C}\right] \mathrm{Me}-5-B D B D$ analog $\left(\left[{ }^{11} \mathrm{C}\right] 9\right) \quad\left[{ }^{18} \mathrm{~F}\right] \mathrm{F}-5-B D B D\left(\left[{ }^{18} \mathrm{~F}\right] \mathbf{5 a}\right)$

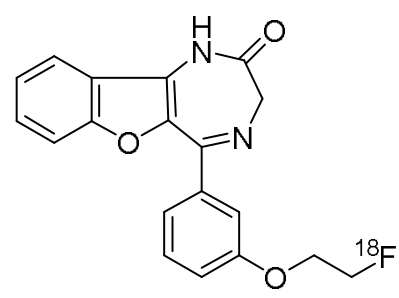

$\left[{ }^{18} \mathrm{~F}\right] \mathrm{FE}-5-\mathrm{BDBD}\left(\left[{ }^{18} \mathrm{~F}\right] 11\right)$ 